\title{
EL DELITO DE ENALTECIMIENTO TERRORISTA. ¿INSTRUMENTO DE LUCHA CONTRA EL PELIGROSO DISCURSO DEL ODIO TERRORISTA O MECANISMO REPRESOR DE REPUDIABLES MENSAJES DE RAPEROS, TWITTEROS Y TITIRITEROS?*
}

\begin{abstract}
Alfonso Galán Muñoz**
Resumen: En este trabajo se analiza el delito de enaltecimiento del terrorismo y de humillación de sus víctimas. Este delito es uno de los numerosos y controvertidos instrumentos creados por el legislador penal español para luchar contra el discurso del odio terrorista; siendo posiblemente el que de forma más frecuente se ha utilizado por nuestros

Recibido: mayo 2018. Aceptado: octubre 2018

* El presente trabajo es una versión ampliada y anotada de la conferencia que bajo el título "El delito de enaltecimiento terrorista. Una difusa figura delictiva" impartió el autor el día 25 de abril de 2018 en el seno del "I Congreso Globalización y lucha contra las nuevas formas de criminalidad transnacional", celebrado en la Universidad Pablo de Olavide de Sevilla, los días 26 y 27 de abril de 2018.

** Titular de Derecho Penal. ORCID ID: /0000-0001-5625-6492

Departamento de Derecho Público. Facultad de Derecho de la Universidad Pablo de Olavide. Dirección Carretera de Utrera, Km.1. Sevilla. Email: agalmun@upo.es
\end{abstract}


Tribunales con tal propósito. Precisamente, su uso reiterado por parte de nuestros tribunales ha dado lugar a una interesante evolución jurisprudencial que es analizada en este trabajo y que ha tratado de definir los contornos de dicho delito con el fin de conseguir que su prohibición resulte compatible con el necesario respeto y garantía de la libertad de expresión que debe brindar todo Estado democrático de Derecho que quiera ser tenido realmente como tal.

Palabras clave: Terrorismo, discurso del odio, libertad de expresión, enaltecimiento del terrorismo, humillación de las víctimas del terrorismo, delito de clima.

\title{
THE CRIME OF GLORIYING OF TERRORRISM. INSTRUMENT TO FIGHT AGAINST THE DANGEROUS HATE SPEECH OF TERRORISM OR A REPRESSIVE TOOL OF REPROACHBLE MESSAGES OF RAPPERS, TWITTERERS AND PUPPETEERS?
}

\begin{abstract}
In this paper is analysed the crime of glorifying terrorism and humiliating its victims. This crime is one of the numerous and controversial legal instruments created by the Spanish penal legislator to fight against the hate speech of terrorism; being possibly the one that more frequently has been used by our Courts with this purpose. Precisely its reiterated use by our Courts has given rise to an interesting jurisprudential evolution that is analysed in this research and that tried to delimit this crime in order to achieve that its prohibition is compatible with the necessary respect and guarantee of the freedom of speech that must be provided by any democratic State of Law that pretend to be really considered as such.
\end{abstract}

Keywords: Terrorism, hate speech, freedom of speech, Glorifying terrorism, Humiliating Victims of terrorism, climate crime.

\section{Introducción}

El terrorismo no es algo nuevo. Desgraciadamente, algunos países, como España, conocen bien y han padecido durante años las consecuencias derivadas de la actuación dentro de su territorio de varias organizaciones terroristas que trataban de conseguir fines políticos diversos mediante el empleo de la violencia, la intimidación y el terror. 
No puede sorprender entonces, que el ordenamiento español fuese, posiblemente junto al vigente en el Reino Unido, el que disponía, de entre los de nuestro entorno y ya antes de la irrupción del denominado terrorismo yihadista, de una mayor variedad de instrumentos penales, tanto materiales como procesales, específicamente destinados a luchar contra este fenómeno delictivo. Unos instrumentos que se caracterizaban tanto por haber procedido a intensificar de forma notable la respuesta punitiva establecida frente a las conductas delictivas que se calificaba como terroristas, como por haber efectuado una notable ampliación y adelantamiento de las posibilidades de intervenir penalmente frente a su posible realización.

Lo primero lo hizo tanto incrementando las penas aplicables a muchos delitos (asesinatos, secuestros, detenciones ilegales, etc...) por el mero hecho de que se hubiesen cometido desde organizaciones terroristas y con las finalidades que éstas perseguían ${ }^{1}$, como estableciendo un régimen especial de determinación y, sobretodo, de ejecución de las penas aplicables a los responsables de dichos delitos mucho más severo y riguroso que el previsto para el resto de conductas delictivas ${ }^{2}$.

Lo segundo lo realizó no solo castigando de forma expresa los actos de participación intentada en dichos delitos terroristas, sino también creando una serie de figuras, (p. ej. la de pertenencia a organización o grupo terrorista (art. 572.2 CP) o la de colaboración puntual con la misma (art. $577 \mathrm{CP})$ ), que

1 Así MUÑOZ CONDE, F. Derecho penal. Parte Especial. Ed. Tirant lo Blanch, Valencia, 2017. p. 781 o CANO PAÑOS. M. A. "La reforma de los delitos de terrorismo", en Estudios sobre el Código penal reformado (Leyes Orgánicas 1/2015 y 2/2015) Ed. Dykinson, Madrid, 2015, p. 913.

2 Así sucedió, por ejemplo, con la LO 7/2003, de 30 de junio, de medidas de reforma para el cumplimiento íntegro y efectivo de las penas, cuyos efectos sobre las penas aplicables a los terroristas, ha comentado, entre otras, LÓPEZ PEREGRÍN, C. “¿Lucha contra la criminalidad mediante el cumplimiento íntegro y efectivo de las penas?" REIC 1 (2003), p. 11 y ss, disponible en http://www.criminologia.net/pdf/reic/ano1-2003/a12003art2. pdf (últ. vis. 2-11-2015). 
han venido a castigar como delitos autónomos y consumados la ejecución de muchas conductas que se cometían dentro o como apoyo a las peligrosas organizaciones terroristas, pero que estaban todavía muy alejadas del comienzo real de la ejecución o incluso de la mera preparación real de los concretos atentados que las caracterizaban.

Los instrumentos y mecanismos de respuesta penal al terrorismo tradicional eran sin duda numerosos, variados, severos y también, por qué no decirlo, bastante controvertidos.

Sin embargo, el terrorismo ha evolucionado o mutado en los últimos tiempos, sobretodo, como consecuencia de la irrupción del denominado terrorismo yihadista; un terrorismo que presenta una serie de peculiaridades que lo distinguen y diferencian claramente del que podríamos denominar como terrorismo "tradicional"3, lo que ha llevado a que se cuestione seriamente si los instrumentos creados para luchar contra esta forma más clásica de terrorismo pueden resultar realmente adecuados y efectivos para hacerlo también contra esta nueva y diferenciada modalidad.

\section{El discurso del odio al infiel como instrumento terrorista.}

Si algo caracteriza y diferencia al terrorismo yihadista es que es una forma de terrorismo que responde a la supuesta existencia de una guerra asimétrica y global que sus integrantes y partidarios han emprendido contra los países a los que consideran contrarios o enemigos de su "pueblo" o comunidad religiosa y de los valores que los caracterizan. Es, por tanto, un terrorismo que no trata de subvertir el orden constitucional del concreto país al que golpea. En ocasiones, ni tan siquiera pretende lo-

3 De "nuevo" y "viejo" terrorismo hablaba, por ejemplo, CANO PAÑOS. M. A. destacando las diferencias entre uno y otro en "Reflexiones en torno al "viejo" y al "nuevo" terrorismo", en REIC 7 (2009), p. 2 y ss, disponible en http://www.criminologia.net/pdf/reic/ano7-2009/a72009art7.pdf (últ. vis. 13-11- 2017). 
grar una finalidad propiamente política respecto a dicho país, (como la de doblegar la voluntad de su opinión pública o de sus políticos para que desistan, por ejemplo, de tomar parte en una determinada campaña militar). Lo que busca en muchos casos es, simple y llanamente, ocasionar dolor y terror a los habitantes del Estado en el que ataca y a los de su entorno como represalia y venganza por los agravios o daños que supuestamente éstos habían contribuido previamente a ocasionar a las personas o colectivos con los que los terroristas se identifican por razones presuntamente religiosas, aunque ni siquiera las conozcan y éstas se encuentren a miles de kilómetros de distancia de donde ellos nacieron, vivieron $y$, finalmente, atentaron.

Es entonces un terrorismo que tiene, ya en su código genético, un marcado carácter trans- o internacional, cualidad que, sin duda, se ha visto muy favorecida por la difusión en un ámbito global de un discurso muy atractivo para determinados colectivos, marcadamente adoctrinador y basado en una concepción completamente manipulada y tergiversada de las tendencias más radicales del Islam que trata, precisamente, de fomentar y de avivar el odio hacia aquellos a los que califica como "infieles" o "enemigos", trasladando una visión completamente maniquea del mundo que clasifica a todas las personas en amigos (fieles, a los que hay que proteger y en su caso vengar) y enemigos (infieles, a los que simplemente hay que exterminar). Un discurso que, de hecho, se ha expandido rápidamente a lo largo y ancho del globo, gracias, entre otras cosas, a su difusión en los modernos medios de información y comunicación y, entre ellos, especialmente en Internet y en las redes sociales desarrolladas en su seno.

Precisamente, esta marcada base adoctrinadora del terrorismo yihadista es la que puede llevar y, de hecho, ha llevado a que muchas personas, que no contaban con apoyo ni contacto alguno con ninguna organización terrorista, (los conocidos como "lobos solitarios"), hayan efectuado, de forma completamente autónoma y por su cuenta y riesgo ataques contra los "enemigos" de su pueblo o religión y en apoyo de la "guerra santa" que creen deben librar contra los Estados "infieles" y sus habitantes, 
incluso aunque ello les haya supuesto tener que perder la propia vida para poder llevarlos a cabo, algo que, indudablemente, plantea serios y evidentes problemas a los tradicionales instrumentos penales de prevención y lucha contra el terrorismo.

Resulta evidente, en tal sentido, que de nada sirve, por ejemplo, la previsión y amenaza de imposición de severas y prolongadas penas de prisión (incluso de la tan cacareada pena permanente revisable) para la comisión de asesinatos terroristas, frente aquel que está dispuesto a dar la vida para cometerlos en aras a defender las ideas que le ha inculcado discurso del odio yihadista ${ }^{4}$.

Precisamente por ello, los diferentes legisladores penales de los países atacados por el terrorismo yihadista y entre ellos, como no, el español, pese a no haber abandonado su tendencia intensificadora de la represión penal referida a esta materia, algo que solo se explica desde un punto de vista preventivo general positivo, cuando no, simplemente desde el más rancio populismo punitivo, han optado por incrementar también el número de figuras delictivas que adelantan la intervención penal respecto a este tipo de actuaciones, viniendo a castigar, entre otras cosas, las iniciales conductas de difusión del discurso del odio que podría llegar a adoctrinar o a captar a futuros terroristas, en lo que supone un claro intento de prevenir los futuros actos lesivos que sus receptores podrían llegar a realizar antes siquiera de que lleguen a plantearse como posibilidad real y concreta el ejecutarlos.

4 Así lo ponen de manifiesto, por ejemplo, NúÑEZ CASTAÑO, E. quien señalaba que respecto a estos terroristas la consecuencia de la no realización del acto terrorista resulta más grave que la posible pena que sufrirían por la imposición del mismo, con lo que la prevención de la norma penal fracasa, ya que "...no es que el "terrorista islámico o religioso" no sea susceptible de ser motivado, sino que es motivado por su propia ley y sus propios sistemas de control social", en "Tendencias político criminales en materia de terrorismo tras la L. O. 2/2015, de 30 de marzo: la implementación de la normativa europea e internacional", en Revista Penal, n 37, 2016, p. 128 o CANO PAÑOS. M. A. "La Reforma penal de los delitos de terrorismo en el año 2015. Cinco cuestiones fundamentales", RGDP 23 (2015), disponible en http://www.iustel.com (últ. vis. 13-03-2018), p. 14, entre otros. 


\section{La proliferación de los instrumentos penales de lucha contra el discurso del odio terrorista}

Como es sabido, lo habitual para castigar a aquella persona que comunica a un tercero un mensaje dirigido o destinado a conseguir que se decida a cometer un delito será considerarle bien como inductor, bien como cómplice psíquico de dicho delito $^{5}$. Sin embargo, para poder calificar y castigar como tal al emisor de dicho mensaje, su receptor, tras recibirlo, tendrá que haber comenzado, cuando menos, a ejecutar el delito propuesto (p. ej. tendrá que haber empezado a matar), lo que, en los casos que nos ocupan y dada la magnitud de los delitos que se pueden realizar, se considera que retrasaría demasiado la intervención penal, privando, por tanto, a dicha rama del Derecho de la eficacia preventiva que debería tener frente a tan peligrosos ataques.

Precisamente, para subsanar dicho aparente déficit preventivo, nuestro Código penal hace ya tiempo que optó por castigar, específicamente y en relación a los delitos terroristas, la mera comunicación o trasmisión publica de mensajes que tiendan a incitar a cometer algún concreto delito de dicha naturaleza, sin exigir que éste hubiese llegado a empezar a ejecutarse.

Evidentemente, el primer y más evidente paso en esta línea consistió en sancionar los actos de codelincuencia intentada que contemplan los art. 17 y 18 de nuestro Código penal (la provocación, la proposición y la conspiración), paso que hace ya muchos años que dio el legislador y que continúa manteniendo a día de hoy, al castigar, de forma expresa, el vigente artículo 579. $3 \mathrm{CP}$, tras la reforma realizada por la LO 2/2015 todas esas posibles actuaciones meramente preparatorias de delitos terroristas.

Se lograría así, por ejemplo, que el castigo de la provocación de un delito terrorista o de la apología, como posible forma

5 Sobre la concreta delimitación de ambas formas de participación intelectual en el delito ajeno, véase, por ejemplo, lo comentado por GÓMEZ RIVERO, M. C. La inducción a cometer el delito. Ed. Tirant lo Blanch, Valencia, 1995. p. 172 y ss. 
de provocación, sirviesen para sancionar a quienes se dedican a utilizar Internet o cualquier medio de comunicación de masas para difundir contenidos que estén directa y expresamente dirigidos a incitar a sus posibles receptores a cometer uno o varios delitos terroristas concretos y determinados, aún cuando estos últimos sujetos, por los motivos que fuesen, no solo no comenzasen a ejecutarlos, sino que ni siquiera hubiesen llegado a conocer o a ser convencidos por el mensaje que trataba de motivarles para que lo hiciesen ${ }^{6}$.

Sin embargo, muchas otras formas de inducción intentada continuarían estando al margen de cualquier relevancia penal, algo que el legislador no parecía dispuesto a tolerar.

Así sucedería, por ejemplo, con aquellos supuestos en los que el acto de inducción intentada no se realizase de forma pública, ante una concurrencia de personas o mediante el uso de un medio de comunicación de masas, sino individualmente. Si bien estas conductas, antes de la reforma que la LO 2/2015, eran consideradas por algunos como susceptibles de ser castigadas como formas de proposición al delito al que incitaban ${ }^{7}$, tras la modificación que de esta forma de codelincuencia intentada ha realizado la referida Ley Orgánica, han pasado a quedar completamente al margen de la delimitación de dicho acto preparatorio

6 BERNAL DEL CASTILLO, J. "Una visión crítica del nuevo delito de provocación al terrorismo del art. 579.1" Revista de Derecho Penal no 33, 2011, p. 70.

7 BARBER BURRUSCO, S. Los actos preparatorios del delito. Ed. Comares, Granada, 2004, p. 206 o sin embargo, MIR PUIG, S. quien, pese al cambio legislativo producido por la reforma realizada por la LO 1/2005 sobre la regulación de dicho acto preparatorio punible, sigue manteniendo que la proposición continúa castigando "la inducción no seguida de ejecución", ya que considera que al castigar el vigente art. $28 \mathrm{CP}$ como autor de un delito no solo a quienes los ejecutan o realizan, sino también a quienes ayudan necesariamente o inducen a otros a ejecutarlo, habrá que continuar entendiendo que haber resuelto cometer un delito, tal y como exige el art. 17.2 $\mathrm{CP}$ al proponente, no supone tener que querer ejecutarlo como autor, dado que cometer el delito significa algo más amplio que ejecutarlo. Derecho penal. Parte General. Ed. Reppertor, Barcelona, 2015. p. 353. 
punible contemplado en nuestro art. $17 \mathrm{CP}$ y, consecuentemente, también del art. 579.3 CP. En efecto, tras dicha reforma la proposición ya solo castigará aquellos actos en los que el proponente se ofrezca a actuar como verdadero autor del delito que pretendía cometer y no solo como su mero inductor; delimitación que evidentemente deja al margen del castigo de la proposición a los meros actos de inducción individual intentada y que justifica que el legislador se haya decidido a castigar tales conductas cuando estén referidas a la futura realización de delitos terroristas mediante la inclusión del nuevo art. 579.2 CP que precisamente sanciona a "...quien solicite a otra persona que los cometa". Esto es, a quien realice una inducción intentada individual o personal referida a la posible comisión por parte de terceros de un delito terrorista concreto; comportamiento que, en caso de que no se hubiese introducido la referida previsión legislativa, permanecería en el ámbito de la más absoluta irrelevancia penal, cuando menos, hasta que no se comenzase a ejecutar el concreto delito que se pretendía incitar a cometer ${ }^{8}$.

8 Sobre esta postura, véase, con mayor extensión GALÁN MUÑOZ, A. “¿Leyes que matan ideas frente a las ideas que matan personas? Problemas de la nueva represión de los mecanismos de captación terrorista tras la reforma del código penal de la LO 2/2015", Revista de Derecho Penal y Criminología, $\mathrm{n}^{\mathrm{o}} .15$ (2016), p. 117 y ss, quien considera que la nueva redacción dada al art. 17.2 CP, que establece que es propositor o proponente quien "invita" a terceras personas a "participar" en el delito que va a cometer y no, como sucedía antes, quien les invitaba "a ejecutarlo", deja a las claras que solo se podrá considerar como proponente a aquel sujeto que invite a otro a que realice una simple aportación al delito que él pretende cometer y dominar, con lo que lo solicitado, siempre y en todo caso, habrá de ser accesorio o coadyuvante de la conducta delictiva que el propio proponente pretendía efectuar (se debe invitar al destinatario de la proposición a participar, no a cometer o ejecutar por su cuenta). Esto determinará que solo se pueda tener por proponente a quien pretenda ser autor o, cuando menos, coautor del delito en el que propone tomar parte al tercero y no a aquel que tan solo pretendiese inducirle a que fuese él mismo quien lo cometiese a título de autor individual y dominándolo de forma exclusiva, con lo que esta forma de inducción intentada e individual quedará al margen de la nueva redacción típica de la proposición. En el mismo sentido, respecto a la delimitación general de la proposición, se manifiesta, por ejemplo, QUINTERO OLIVARES, G. Comentarios al Código penal español. Tomo I. Ed. Aranzadi, Cizur Menor, 2016, p. 180. 
Ahora bien, el empeño del legislador por castigar los meros intentos de incitar a terceros para que cometan delitos terroristas no terminó aquí. También le llevó a castigar, en el artículo 579.1 CP, no solo a quien difunda públicamente mensajes o consignas que tengan por finalidad incitar a sus receptores a cometer algún delito terroristas, sino también a quien trasmita, de la misma forma, esto es, públicamente, algún contenido que, sin estar expresamente dirigido a fomentar la comisión de un concreto delito terrorista, sí que resulte idóneo para incitar a sus receptores a que lo ejecuten?.

Con esto último se conseguiría que el Derecho penal pueda castigar a quien difunda de forma pública (esto es, no individualizadamente, sino ante o hacia un colectivo) una consigna o un mensaje que simplemente resulte objetivamente adecuado, desde un punto de vista ex ante, para generar la idea en quienes lo reciban de cometer un delito terrorista y lo distribuya cuando menos conociendo y teniendo consciencia de tal cualidad del mensaje, por más que lo haga sin intención alguna de conseguir dicho efecto.

Lo primero hace posible que este precepto pueda servir para castigar la difusión colectiva de contenidos que no inciten expresa y claramente a cometer un acto terrorista, pero que sí resulten aptos o adecuados para conseguirlo, al trasmitir un mensaje que implícitamente (no de forma expresa) sea idóneo para generar dicha idea en su receptor. Lo segundo abre las puertas a que se pueda sancionar penalmente la difusión de tales contenidos, aunque se lleve a cabo por alguien que al transmitirlos no

9 Muy crítico con dicha ampliación se muestra BERNAL DEL CASTILLO, J. por entender que la misma introduce en nuestro ordenamiento una modalidad preparatoria punible indeterminada y diferente de la provocación propiamente dicha que parece tendrá que servir de tipo de recogida que permita castigar actos enaltecedores o justificadores del terrorismo o de los terroristas tan genéricos o indirectos que no se puedan encuadrar en el delito de apología. En "El enaltecimiento del terrorismo y la humillación de sus víctimas como formas del "discurso del odio"”, en Revista de Derecho Penal y Criminología, $n^{o} .16$ (2016), p. 40. 
buscaba o no se puede demostrar que buscase incitar a sus destinatarios a efectuar el delito en cuestión. Esto es, a aquellos sujetos que lo hubiesen difundido sin actuar con la finalidad o dolo directo de inducir a sus receptores a cometer un delito terrorista, pero sí con un dolo que abarcase la idoneidad del contenido distribuido para poder llegar a hacerlo ${ }^{10}$.

Evidentemente, el paso legislativo dado amplía enormemente el número de los posibles mensajes de apoyo al discurso yihadista cuya difusión pública podría llegar a ser penalmente relevante, pero lo hace a costa de difuminar y desdibujar de forma notable los caracteres que tradicionalmente habían delimitado a los mensajes incitadores de delitos que podría llegar a tener relevancia penal.

Resulta innegable, en tal sentido, que aunque un mensaje no incite de forma manifiesta y explícita a sus destinatarios a cometer un delito de terrorismo, sí que podrá, sin embargo, resultar idóneo para incitarles a realizarlo dependiendo de factores tales como el concreto momento en que se distribuya o quienes pudiesen ser, en concreto, sus receptores.

Así, por ejemplo, podría suceder que la difusión de un mensaje radicalmente crítico con uno de responsables de los cuerpos y fuerzas de seguridad del Estado pudiese ser considerado como constitutiva de este delito si se ejecuta en un momento especialmente conflictivo (p. ej. cuando precisamente dicho cuerpo e individuo se encontraban inmersos en una operación militar criticada por los terroristas que clamaban venganza contra sus integrantes por su realización) y se dirige además a quienes comparten y apoyan los ideales sostenidos y los medios violentos empleados por los terroristas o la "guerra santa" que éstos supuestamente libran, resultando, sin embargo, absolutamente irrelevante, a efectos de dicha figura, si se hubiese difundido en un contexto histórico distinto o entre quienes no solo no compartían los postulados yihadistas, sino que los rechazaban de forma tajante.

10 GALÁN MUÑOZ, A. Op. cit. ant. p. 119 y ss. 
Muchos son, por tanto, los factores y variables que han de tenerse en cuenta a la hora de calificar un mensaje como inductoramente idóneo y peligroso y, consecuentemente, típico de este delito, lo que, si bien convertirá a esta figura en un instrumento adecuado para castigar muchas conductas susceptibles de inducir o fomentar la realización de delitos terroristas que escaparían a los contornos delimitadores de los actos preparatorios punibles anteriormente comentados, lo hace a costa, como ya hemos señalado, de restar certeza y seguridad jurídica a la delimitación de los mensajes penalmente prohibidos por nuestro Derecho penal, coste que no se puede, ni se debe menospreciar ${ }^{11}$.

Pese a todo, esta figura todavía requiere que el mensaje difundido resulte idóneo, desde un punto de vista ex ante, para incitar a sus posibles destinatarios a cometer un concreto y determinado delito de terrorismo. En concreto, el delito que serviría como referente para determinar la pena que se le habría de imponer al emisor del mensaje prohibido por el art. $579.1 \mathrm{CP}$, lo que obligará a que el mensaje difundido haya de tener un contenido que haga perfectamente determinable, desde un punto de vista ex ante, el delito que podía llegar a incitar, consiguiéndose así definir y determinar, en cierta medida, la clase de contenidos cuya difusión podría entrar dentro del tipo delictivo de dicho precepto. Sin embargo y al mismo tiempo, esta exigencia también llevará a que esta figura no resulte plenamente eficaz a la hora de luchar contra algunas de las manifestaciones más habituales del discurso del odio propio del terrorismo yihadista. Un discurso que, en muchas ocasiones, trata de incitar a sus receptores a que cometan, no actos o ataques terroristas concretos, de-

11 En similares términos CANO PAÑOS., M. A. "La reforma de los delitos de terrorismo" cit. ant. p. 945. Críticos con la anterior redacción de este precepto también se mostraban CANCIO MELIÁ, M. En "Delitos de organización: Criminalidad organizada común y delitos de terrorismo" en Estudios sobre las reformas del Código penal operadas por las LO 5/2010, de 22 de junio, y 3/2011, de 28 de enero". Civitas. Cizur Menor (Navarra) 2011, p. 665 y BERNAL DEL CASTILLO, J. "Una visión crítica del nuevo delito de provocación al terrorismo del art. 579.1” Op. cit. ant. p. 72. 
terminados o cuando menos determinables, sino cualquiera que puedan realizar contra aquellos a los que califica de "infieles".

Teniendo en cuenta dicho hecho, nuestro legislador decidió dar un paso más en la lucha contra esta clase discurso y castigó como delito de colaboración terrorista del apartado 2 del art. $577 \mathrm{CP}$ el efectuar cualquier actividad de adoctrinamiento activo (individual o público) que esté dirigida o, y esto es resulta fundamental, que "por su contenido resulte idónea para incitar a cometer cualquiera de los delitos de terrorismo".

Se castiga con esta última expresión, la difusión de doctrinas, de meras ideas, que, aunque no estén dirigidas a incitar pública ni expresamente a cometer delitos terroristas, ni se efectúen con intención o dolo de motivar a realizarlos (solo hace falta que sean idóneas para logarlo y que quien las transmita conozca dicho carácter), sí que pueden llevar a su receptor a cometer algún delito terrorista en general, por más que dicho posible y futuro delito a cometer ni esté definido en el mensaje, ni pueda ser fijado ni predeterminado atendiendo a su contenido ni al contexto en que se emitió ${ }^{12}$.

12 Así lo indica tanto que este precepto establezca el castigo de los actos adoctrinadores que se dirijan o que simplemente resulten idóneos para incitar a efectuar "cualquier" delito terrorista y no "alguno" de ellos, como, por ejemplo, hacían las conductas incitadoras indirectas o implícitas de delitos concretos castigadas por el art. 579.1. CP, como que el que el delito de colaboración terrorista en general, contemplado en el art. $577 \mathrm{CP}$ sea una figura que castiga el suministro, por parte de personas, no integradas en una organización o grupo terrorista, de ayudas o contribuciones genéricas a cometer delitos de dicha naturaleza y no las ayudas puntuales que simplemente tiendan a facilitar la comisión de uno o varios de ellos determinados, señalando en tal sentido NÚNEZ CASTAÑO, E. que la colaboración terrorista "debe ser genérica, es decir no vinculada a una actividad concreta sino que conste en un apoyo genérico..." mientras que “...si este apoyo material se concreta en una determinada conducta delictiva, la colaboración cede ante la coautoría o la complicidad". En Los delitos de colaboración con organizaciones y grupos terroristas. Ed. Tirant lo Blanch, Valencia, 2013, p. 145; postura que también comparte, entre otros, GARCÍA ALBERO, R. Comentarios al Código penal Español, Tomo II Ed. Aranzadi, Cizur Menor, 2017, p. 1926. 
Lo primero que llama la atención de esta figura es que sancione y prohíba transmitir "doctrinas" y no de forma general ideas o contenidos objetivamente peligrosos, algo que, a nuestro modo de ver, no es en modo alguno casual, sino producto de una muy meditada decisión legislativa, ya que, dicha expresión, si bien mantiene al margen de esta figura, por ejemplo, a todas aquellas actuaciones que podrían realizar aquellos periodistas o cómicos que trasmitan mensajes o viñetas que critiquen o se mofe de las ideas y símbolos que defienden los seguidores de los terroristas, por más que resulten indudablemente idóneas para fomentar la realización de actos terroristas en venganza por su difusión (piénsese, por ejemplo, en las viñetas del Charlie Hebdo), sí que permitirá castigar penalmente la instrucción, transmisión o enseñanza de ideas, creencias u opiniones que se correspondan con los postulados defendidos por el discurso de odio terrorista y se transmitan conociendo su peligrosidad delictiva incitadora.

Podría pensarse entonces que la creación de esta figura es preventivamente positiva y técnicamente acertada, ya que servirá para luchar contra alguna de las modalidades más comunes de apoyo ideológico y fomento de la comisión de actos terroristas que escapaban de las figuras anteriormente comentadas (las que no incitan ni explicita, ni implícitamente a cometer un delito concreto), al tiempo que evitaban castigar penalmente la difusión de ideas que se consideran deben estar protegidas por la libertad de expresión (las no concordantes con las doctrinas terroristas por más peligrosas que puedan ser).

Sin embargo, la pregunta surge de forma inmediata. Si este delito solo permite sancionar la transmisión de ideas defendidas desde el terrorismo (las adoctrinadoras) y no de las que, aunque no tengan dicha naturaleza, pueden llevar, incluso de forma más idónea y segura que las referidas doctrinas, a generar la comisión de delitos de terrorismo (burlas de Alá, sátiras de líderes religiosos o políticos defendidos desde el entorno terrorista etc...), ¿no estaremos dejando de perseguir la transmisión de ideas por la peligrosidad inductora que presentan 
con respecto a la realización de delitos de delitos de terrorismo, para pasar a prohibir y castigar directamente el simple mantenimiento o transmisión de ideas que no nos gustan? ¿No supone esto negar la posibilidad de defender dichas ideas y postulados (los sostenidos por los terroristas) y, por tanto, tratar imponer un pensamiento único sobre los temas que se ponen en tela de juicio desde dichos movimientos acabando de esa forma, radicalmente, con el pluralismo, la libertad de opinión, de expresión e información que debería existir en relación al debate relativo a tales cuestiones? ${ }^{13}$.

Podría tratar de responderse a esta pregunta señalando que, en realidad, dichos temores resultan exagerados, por cuanto el referido delito no castiga simplemente la enseñanza o transmisión de ideas, postulados o doctrinas sostenidos o apoyados por los terroristas, por muy radicales que puedan ser, sino solo las de aquellas que resulten idóneas, en el caso concreto, para poder incitar a sus destinatarios a cometer delitos terroristas en general.

Sin embargo, a nuestro modo de ver, esta posible interpretación se enfrentaría a un claro y grave problema, ya que, al castigarse en esta figura, como hemos visto, la mera transmisión de determinadas ideas o doctrinas que ni tienen que contener una manifiesta y expresa incitación a cometer delitos terroristas (puede ser tácita o implícita), ni tienen que resultar adecuadas desde un punto de vista ex ante para instigar a sus posibles receptores a cometer un concreto y previsible delito de dicha

13 En este sentido, hay que recordar que, como señalaba VIVES ANTÓN, T. S. resultaría del todo incongruente con la afirmación de la existencia de la libertad ideológica y de expresión de los Estados democráticos que fuesen precisamente dichos Estados los que decidiesen por los ciudadanos, supuestamente libres y autónomos, qué clase de ideas podrían llegar a conocer y cuáles no, ya que al hacerlo se les estaría negando la racionalidad, autonomía y libertad que supuestamente el ordenamiento les reconoce. En "Sistema democrático y concepciones del bien jurídico; el problema de la apología del terrorismo", en Terrorismo y proceso penal acusatorio. Ed. Tirant lo Blanch, Valencia, 2006. p. 41. 
naturaleza (pueden inducir a cometerlos de forma genérica), se desdibujan hasta tal punto los referentes conforme a los que se debería valorar la idoneidad incitadora que las ideas o informaciones típicamente relevantes $\mathrm{y}$, por tanto, prohibidas por este delito, que se hace realmente difícil el determinar cuáles de entre las ideas "adoctrinadoras", al ser difundidas, podrán resultar idóneas para inducir a alguno de sus receptores a cometer algún delito terrorista y cuáles, sin embargo, al no serlo, se mantendrán en el ámbito de la atipicidad.

Así, por ejemplo, ¿afirmar en un debate televisado con gran audiencia que el tratamiento que estaban recibiendo los musulmanes en un determinado conflicto bélico era delictivo y que la comunidad internacional no estaba haciendo nada para impedirlo, como había previamente afirmado y defendido un determinado grupo u organización terrorista que llamaba, precisamente por ello, a la "guerra santa contra los infieles" como represalia, trasmitiría una idea "adoctrinadora" y típica de este delito, por ser adecuada o idónea para que alguno de sus numerosos e indeterminados posibles receptores pudiese decidirse a incorporarse a dicha guerra cometiendo un atentado terrorista de cualquiera naturaleza o, simplemente, integrándose o colaborando con la referida organización o grupo?

Como se puede comprobar, no es fácil responder con la suficiente contundencia y seguridad a dicha cuestión y esto muy previsiblemente llevará a que muchos ciudadanos se abstengan de manifestarse en favor de cualquiera de los postulados que defiendan los terroristas, por si acaso la difusión de su postura se pudiese llegar a considerar como peligrosa y, por tanto, típica de este delito y ello pudiese llevarles a sufrir alguna clase de responsabilidad penal, provocándose así un efecto de desaliento, (Chilling Effect), en los ciudadanos respecto a la posible realización por su parte de actos legítimos de ejercicio de su libertad de expresión que determinará una cuestionable $\mathrm{y}$, a nuestro modo de ver, desproporcionada limitación de dicha libertad fundamental, lo que resulta ciertamente difícil de admitir en un Estado democrático de Derecho que realmente pueda ser tenido por tal. 
Si a esto se añade que además, el apartado 3 del referido art. $577 \mathrm{CP}$ prevé incluso el castigo de las comentadas y controvertidas conductas adoctrinadoras cuando se efectúen por imprudencia, esto es, por ejemplo, por un sujeto que ni siquiera fuese consciente de la peligrosidad del mensaje que estaba trasmitiendo, sino que lo difundiese por no haberlo considerado peligroso pese a serlo, no quedará más remedio que entender que nuestro legislador ha ido demasiado lejos en su empeño de luchar contra el discurso del odio yihadista, ya que al crear este delito dirige una prohibición penal a los ciudadanos que previsiblemente les llevará a no difundir ninguna de las ideas sostenidas por los terroristas, aunque no las consideren peligrosas, ante el simple temor de poder equivocarse en dicha valoración y que ello les pudiese llevar a ser sancionados penalmente.

Habrá que considerar, por tanto, que el delito de adoctrinamiento activo del art. $577 \mathrm{CP}$, cuando castiga al transmisión de doctrinas simplemente idóneas para generar la comisión de cualquier delito terrorista sin más, desalienta a los ciudadanos del realizar actos legítimos de ejercicio del derecho a su libertad de expresión, con lo que limita de forma desproporcionada dicho derecho fundamental y se convierte en un delito manifiestamente inconstitucional.

Ahora bien, el arsenal punitivo de nuestro ordenamiento frente al discurso del odio terrorista no acaba con esta controvertida figura.

Ya antes de la irrupción del terrorismo yihadista y de la ampliación de instrumentos penales específicamente dirigidos a perseguir y castigar la difusión del discurso del odio que le es propio, nuestro Código penal contemplaba algunos instrumentos que servían y trataban de luchar contra la difusión de determinadas ideas y mensajes que apoyaban o sustentaban la realización de actos propios de lo que hemos denominado como "terrorismo tradicional" y que, evidentemente, también pueden ser y han sido utilizados contra el discurso propio del terrorismo yihadista. Se trata de los delitos de enaltecimiento o justificación 
del terrorismo y del de humillación a las víctimas contenidos en el art. 578 CP; unos delitos estos cuya persecución y sanción judicial parecen estar viviendo en los últimos tiempos una especie de "edad de oro" en nuestro país, lo que ha llevado a centrar nuestro atención en su estudio.

\section{El delito de enaltecimiento del terrorismo y su cuestionada fundamentación}

Antes de la reforma realizada por la LO 7/2000 se solía considerar que los actos de justificación y enaltecimiento del terrorismo de los terroristas solo podían ser castigados cuando supusiesen la realización de un acto de apología de los que hablaba y aún hoy habla el art. 18 de nuestro Código penal, lo que suponía que solo se pudiesen sancionar los actos enaltecedores o justificadores que estuviesen expresa y directamente dirigidos a promover la comisión de un concreto y determinado delito terrorista $^{14}$.

Sin embargo, la entrada en vigor de la referida Ley Orgánica supuso una auténtica revolución respecto a la posible calificación penal de estas conductas, ya que introdujo en nuestro ordenamiento el en aquel entonces novedoso delito contenido en el art. $578 \mathrm{CP}$ que castigaba de forma expresa tanto la mera conducta de enaltecer o justificar públicamente los actos delictivos propios de esta forma de criminalidad o a quienes los realizaban, como la de humillar o menospreciar a sus víctimas, afirmándose en la propia Exposición de Motivos de la comentada Ley Orgánica, que la expresa sanción penal de tales actuaciones se fundamentaba en que su realización constituía “...no sólo un refuerzo y apoyo a actuaciones criminales muy graves y a la sostenibili-

14 Sobre esta situación, véase lo comentado, por ejemplo, por CARBONELL MATEU, J. C. "Apología de los delitos contra la seguridad interior del Estado", en Comentarios a la legislación penal, Tomo II: El Derecho penal del Estado democrático, Ed. Edersa Madrid, 1983, p. 245 o por MUÑOZ CONDE, F. Derecho penal. Parte Especial, cit. ant. p. 789. 
dad y perdurabilidad de las mismas, sino también otra manifestación muy notoria de cómo por vías diversas generará el terror colectivo para hacer avanzar los fines terroristas".

Pese al cambio legislativo producido, fueron muchos los que continuaron defendiendo que este delito seguía sancionando tan solo aquellas conductas enaltecedoras o justificadoras o humillantes de las víctimas que resultasen apologéticas del terrorismo y, por tanto, constitutivas de actos de provocación y directamente incitadores de la comisión de concretos delitos de dicha naturaleza ${ }^{15}$. Otros, sin embargo, y de forma más correcta, a nuestro modo de ver, afirmaban que dicha posible interpretación se acomodaba mal con el nuevo tenor literal de este delito, ya que resultaba obvio y patente que ninguno de los elementos configuradores de su tipo de injusto obligaba a limitar su posible campo de aplicación a aquellos supuestos en los que hubiese un acto de incitación expresa ni directa a la comisión de uno de dichos ataques ${ }^{16}$.

15 NÚNEZ CASTAÑO, E. Los delitos de colaboración con organizaciones y grupos terroristas cit. ant. p.170.

16 En este sentido, señalaba CARBONELL MATEU, J. C. que “...El "nuevo" delito de enaltecimiento - primera parte de la alternativa - no es otra cosa que la reintroducción de la apología del terrorismo, desprovista de los atributos propios de los actos preparatorios; pues ya no exige incitación, ni directa ni indirecta, a la comisión de futuros delitos de terrorismo; al menos, no lo hace literalmente", en "Crítica a los sentimientos como bien jurídico-penal: el enaltecimiento del terrorismo y la humillación a las víctimas "más allá de la provocación y la injuria"”, en Terrorismo, sistema penal y derechos fundamentales. Ed. Tirant lo Blanch, Valencia, 2018, p. 342; mientras CAMPO MORENO, J. C., citando la STS n ${ }^{\circ} 481 / 2014$ de 3 de junio, afirmaba que la apología del art. 18 CP exige la invitación directa a cometer un delito concreto, el enaltecimiento o justificación del terrorismo del art. $578 \mathrm{CP}$ "constituye una forma autónoma de apología caracterizada por su naturaleza genérica, sin integrar una provocación ni directa ni indirecta a la comisión de un delito concreto", en Comentarios a la reforma del Código penal en materia de terrorismo: L.O. 2/2015, Ed. Tirant lo Blanch, Valencia 2015, p. 71; postura coincidente con la sostenida por MANJÓN CABEZA, A. en "Apología del terrorismo", en Estudios penales en recuerdo del profesor Ruiz Antón, Ed. Tirant lo Blanch, 2004, p. 580; la de RAMOS VÁZQUEZ, J. A. "Presente y futuro del delito de 
En efecto, el tenor literal del delito del art. $578 \mathrm{CP}$ en modo alguno alude o exige que los actos de enaltecimiento, justificación o humillación de los que habla tengan que estar dirigidos a incitar a otros a cometer uno o varios delitos terroristas determinados. Más bien parece que, para poder apreciar este delito, bastaría con que se constatase que se había realizado una conducta que trasmitiera alguno de los mensajes de los que dicho precepto habla. Esto es, un mensaje emitido públicamente que ensalce, elogie o alabe actos terroristas previamente cometidos o a quienes los cometieron o uno que humille o menosprecie a sus víctimas, aún cuando éste último no se hubiese difundido públicamente ${ }^{17}$.

El problema de esta última propuesta parecía evidente, sobretodo, en lo que se refería a las modalidades de enaltecimiento o justificación del terrorismo o de los terroristas, ya que si se interpreta este delito de forma que castigue penalmente la mera realización de actos comunicativos no expresa y directamente dirigidos a fomentar o a incitar la comisión de delitos terroristas concretos, parece que vendría a prohibir y sancionar la simple emisión y el mantenimiento de muchas de las más habituales manifestaciones o expresiones de apoyo o respaldo de los planteamientos sostenidos por los terroristas, lo que convertiría en penalmente relevantes el mero hecho de comunicar o difundir públicamente tales posturas o ideas, algo que podría

enaltecimiento y justificación del terrorismo", en AFCUC, 12, 2008. 784, MIRA BENAVENT, J. "El delito de enaltecimiento del terrorismo, el de humillación a las víctimas del terrorismo y la competencia de la Audiencia Nacional: ni delito, ni terrorismo, ni competencia de la Audiencia Nacional", en Terrorismo, sistema penal y derechos fundamentales. Ed. Tirant lo Blanch, Valencia, 2018, p. 303, ALONSO RIMO, A. "La criminalización de la preparación delictiva través de la Parte Especial del Código penal. Especial referencia a los delitos de terrorismo" Terrorismo, sistema penal $y$ derechos fundamentales. Ed. Tirant lo Blanch, Valencia, 2018, p. 232; o MUÑOZ CONDE, F. En Derecho penal. Parte Especial, cit. ant. p. 790, entre otros.

17 BERNAL DEL CASTILLO, J. "El enaltecimiento del terrorismo y la humillación de sus víctimas como formas..." cit. ant. p. 22 y 28. 
entrar en contradicción con el respeto y garantía de las libertades fundamentales de expresión y de opinión de los ciudadanos.

La cuestión entonces estaría en encontrar el modo por cual la prohibición y la sanción penal de la difusión de dichas ideas y opiniones, no directamente apologéticas ni incitadoras de concretos actos terroristas no supondrán una desproporcionada e inconstitucional limitación de unas libertades tan fundamentales para la propia existencia y normal funcionamiento de las sociedades democráticas como las citadas.

Para dar solución a dicho posible problema, quienes negaban el carácter necesariamente apologético de las conductas sancionadas en este delito acudieron rápidamente a la utilización de uno de los mecanismos que los tribunales, tanto nacionales como internacionales, habían considerado como justificadores y legitimadores de la posible prohibición y persecución penal de la emisión de ciertos discursos.

Estamos hablando de la prohibición de lo que se ha venido a denominar como "discursos del odio".

El punto de partida de la prohibición de esta clase de discursos es la conocida como paradoja de la tolerancia de la que ya hablaba POPPER.

A juicio de este autor, debía tenerse presente que, si bien los Estados democráticos se caracterizan por la tolerancia a la difusión y el mantenimiento de toda clase de ideas, ello no debería hacer olvidar que "...la tolerancia ilimitada debe conducir a la desaparición de la tolerancia. Si extendemos la tolerancia ilimitada aun a aquellos que son intolerantes; si no nos hallamos preparados para defender una sociedad tolerante contra las tropelías de los intolerantes, el resultado será la destrucción de los tolerantes y, junto como ellos, de la tolerancia. Con este planteamiento no queremos significar, por ejemplo, que siempre debamos impedir la expresión de concepciones filosóficas intolerantes; mientras podamos contrarrestarlas mediante argumentos racionales y mantenerlas en jaque ante la opinión pública, su prohibición sería, por cierto, poco prudente. Pero 
debemos reclamar el derecho de prohibirlas, si es necesario por la fuerza, pues bien puede suceder que no estén destinadas a imponérsenos en el plano de los argumentos racionales, sino que, por el contrario, comiencen por acusar a todo razonamiento; así, pueden prohibir a sus adeptos, por ejemplo, que prestan oídos a los razonamientos racionales, acusándolos de engañosos, y que les enseñan a responder a los argumentos mediante el uso de los puños o las armas", lo que le llevó a concluir que “... Deberemos reclamar entonces, en nombre de la tolerancia, el derecho a no tolerar a los intolerante." 18 (la negrita es nuestra).

Se parte, por tanto, de que las sociedades tolerantes pueden e incluso deben protegerse ante los movimientos e ideas intolerantes prohibiéndolas, para evitar que éstos puedan terminar triunfando y utilicen la tolerancia de las sociedades democráticas precisamente para acabar con ella y, como consecuencia, también con la democracia.

Este argumento, como ya hemos señalado, ha sido utilizado reiteradas ocasiones, tanto por nuestro propio Tribunal Constitucional como por otras cortes internacionales (p. ej. TEDH) para considerar como legítimas limitaciones y prohibiciones de determinados discursos intolerantes o generadores del odio hacia ciertos colectivos, como sucedió, por ejemplo, con los justificadores del holocausto judío en la segunda guerra mundial o aquellos que respaldaban y respaldan movimientos tan peligrosos e intolerantes como los defendidos en su día por los nazis en países como Alemania ${ }^{19}$. No puede sorprender entonces que este concepto fuese rápidamente traído a colación en respaldo de la posible legitimidad de la prohibición del mantenimiento y defensa públicas de determinadas posiciones e ideas,

18 POPPER, K. La sociedad abierta y sus enemigos. Ed. Paidós, Barcelona, 2006, Nota al pie 4 del capítulo 7, en p. 585.

19 Sobre este tema, resulta interesante la lectura de RODRÍGUEZ MONTAÑÉS, T. Libertad de expresión, discurso extremo y Delito. Una aproximación desde la constitución a las fronteras del derecho penal. Ed. Tirant lo Blanch, Valencia, 2011, p. 116 y ss, o de ALCACER GUIRAO, R. En "Opiniones constitucionales", Indret, 1/2018, p. 2 y ss. 
como las sostenidas por los terroristas; ideas éstas que, como vimos, tratan precisamente de fomentar la intolerancia y generar o de apoyar un clima de odio y rechazo hacia aquellos a los que se califica y considera como "enemigos" o infieles a los que hay que exterminar o de los que se hay que vengar por los supuestos daños que han contribuido a ocasionar.

De esta forma y a juicio de los defensores de esta propuesta, el delito de enaltecimiento y justificación terrorista no castigaría ya actuaciones apologéticas o incitadoras de actos terroristas, sino la mera difusión de informaciones intolerantes que, al legitimar y alabar a la violencia intolerante y a quienes la ejercen resultan idóneas para contribuir a generar o mantener un entorno social (un clima) de hostilidad odio u aversión hacia determinados colectivos o instituciones, que podría llevar a que quienes vivan en dicho clima se puedan decidir a realizar cualquier clase de delito terrorista contra sus integrantes.

Ahora bien, y como ya hemos visto, el art. $578 \mathrm{CP}$ no contempla un único delito, sino dos. Por una parte, estaría el delito de enaltecimiento o justificación pública del terrorismo del que acabamos de hablar y, por otra, el de humillación o menosprecio de sus víctimas.

Podría pensarse que el hecho de que esté último delito (el de humillación) aluda y sancione conductas que denigran o menosprecian a las víctimas de terrorismo o a sus familiares ${ }^{20}$ daría ya razón de la legitimidad de su existencia, ya que, al prohibir y castigar mensajes que atacarían al honor o a la integridad moral de los integrantes de dichos colectivos, difícilmente se podrían entender que estableciese una prohibición que restringiese o afectase en modo indebido al ejercicio legítimo del derecho a la libertad de expresión.

20 CARBONELL MATEU, J. C. critica, acertadamente a nuestro modo de ver, que en este tipo se aluda a los familiares de las víctimas en general que sin delimitar adecuadamente el ámbito o extensión de dicho parentesco. En "Crítica a los sentimientos como bien jurídico-penal: ..." cit. ant. p. 343. 
Sin embargo, no tardó demasiado la doctrina en señalar que, en realidad, esta figura no tenía por finalidad la de proteger tales valores individuales o, por lo menos, no la tenía de forma exclusiva. Así se deducía del hecho de que la comentada figura castigue al autor de tales conductas denigrantes con total independencia de que el sujeto o los sujetos supuestamente afectados por su realización hubiesen fallecido con anterioridad a su comisión, de que se hubiesen sentido ofendidos o no por las manifestaciones realizadas, de que hubiesen denunciado su difusión o no, o de que incluso hubiesen perdonado expresamente a aquellos que la efectuaron ${ }^{21}$. Mantener en estas condiciones que lo castigado por este delito era simplemente la ejecución de una forma agravada o cualificada de injuria que atacaba al honor individual de las víctimas del terrorismo o sus familiares y que esto, por sí solo, era lo que justificaba la existencia y legitimidad de este delito resultaba realmente difícil, por no decir, imposible ${ }^{22}$.

El carácter individualmente indisponible de la persecución y castigo penal de este tipo de actuaciones por parte de sus aparentes víctimas directas ponía de manifiesto que su injusto trascendía, en realidad, al mero interés personal de dichos individuos ${ }^{23}$ y presentaba un componente más supraindividual

21 MIRA BENAVENT, J. Op. cit. ant. p. 306.

22 En tal sentido, señala CARBONELL MATEU, J. C. que “...Habría que preguntarse, con todo, si el precepto no va bastante más allá de la injuria y considera, por tanto, la quiebra de intereses distintos al honor. Sólo eso explicaría que estemos ante un delito perseguible de oficio y no a instancia departe, en el que el perdón o la absoluta indiferencia del presumiblemente ofendido no juegan papel alguno.", lo que poco después le lleva a afirmar que “...Descartados el honor y el riesgo de comisión de actos terroristas, sólo los sentimientos de repulsa ante conductas muchas veces repugnantes parecen explicar la introducción de esta variante en el artículo 578”. En "Crítica a los sentimientos como bien jurídico-penal: ..." cit. ant. p. 344.

23 En esta línea, ha de destacarse que tampoco compartimos la postura mantenida por MIRÓ LLINARES, F., quien se manifestaba en favor de entender que este delito afectaba "al honor o dignidad del colectivo de víctimas del terrorismo y de la propia sociedad". "Derecho penal y 140 caracteres. Ha- 
o social, cuya persecución y castigo, evidentemente, no podía quedar, ni quedaba en manos individuales. Un componente que, de hecho, parecía estar muy relacionado con el peligroso discurso odio terrorista que pone en peligro a toda la sociedad democrática y que, precisamente por ello, obliga al legislador tener que tratar de erradicarlo, aún cuando no fuese perseguido por sus víctimas directas. Se entendía entonces, que los actos de humillación a las víctimas del terrorismo se diferenciaba de los delitos de injurias, precisamente, porque venía a castigar una parte de aquel discurso que trata, por un lado, de ensalzar a los verdugos, justificando y alabando sus conductas o convirtiéndolos en una suerte de héroes plenos de virtudes, a los que se debe imitar, mientras que, por otro y simultáneamente, denigra y humilla a las víctimas, con el fin de transformarlas en meras cosas, carentes de cualquier valor, en "perros infieles" a los que es legítimo y necesario exterminar.

Lo cierto y verdad es que la consideración de todos los mensajes prohibidos por el delito ahora analizado como manifestaciones del discurso intolerante o del odio terrorista en modo alguno acabó con la polémica que rodeaba a la legitimidad de dicha figura.

Ésta continuó y, de hecho, continúa siendo cuestionada por muchos, ya que no son pocos los que entienden que la escasa lesividad que en muchas ocasiones presentan las conductas que este precepto penal venía a prohibir y sancionar, una vez que se afirma que ni siquiera tienen que ser incitadoras directas o indirectas de la comisión de delitos, no justifica la limitación de

cia una exégesis restrictiva de los delitos de expresión", Cometer delitos en 140 caracteres. El Derecho penal ante el odio y la radicalización en Internet. Ed. Marcial Pons. Madrid, 2017, p. 40, ya que ni creemos que el tipo delictivo analizado exija que sus conductas típicas presenten una idoneidad lesiva tan amplia para poder ser tenidas como tales, ni el referido autor explica en qué modo el mero acto de humillación de una víctima en concreto de un determinado delito terrorista que el art. $578 \mathrm{CP}$ castiga, puede afectar a la dignidad o el honor del resto de víctimas que componen dicho colectivo ni menos aún del conjunto de la sociedad. 
derechos que su castigo y persecución penal vendría a ocasio$\operatorname{nar}^{24}$, ni tampoco da razón del especial tratamiento que otorga a las conductas de humillación a las víctimas frente a la que se establece para las actuaciones que son sancionadas por los delitos generales de injurias ${ }^{25}$.

$\mathrm{Si}$ a ello se le une la existencia de los muy numerosos y controvertidos instrumentos penales que, como hemos visto, se han ido creando para luchar contra la difusión de las ideas terroristas, no puede sorprender que se haya afirmado que nuestro legislador ha introducido en nuestro ordenamiento una “... preocupante batería de posibilidades de intervención del aparato de persecución penal abierta por los delitos de manifestación" que vulneraría “...lo que la Constitución de un Estado de Derecho permite", llegando incluso a afirmarse, en esta misma línea de pensamiento, que en conjunto parecía que lo que el legislador pretendía al crear todas estas figuras era criminalizar a todo tipo de simpatizantes o supuestos simpatizantes de los terroristas ${ }^{26}$, para lo cual, como señalaba GARCÍA ALBERO, el legislador español ya solo le tenía que franquear un último límite "...Un límite a trazar de acuerdo con principio rector que podría ser enunciado de esta guisa "o estás contra el terrorismo o formas parte de él'"27.

La polémica estaba servida y se vio acrecentada por el incesante incremento del número de procedimientos judiciales abiertos en relación con la posible comisión de los delitos contemplados en el art. $578 \mathrm{CP}$ desde su aprobación y entrada

24 Así, por ejemplo, CARBONELL MATEU, J. C. En "Crítica a los sentimientos como bien jurídico-penal: ..." cit. ant. p. 353.

25 MIRA BENAVENT, J. Op. cit. ant. p. 317.

26 CANCIO MELIA, M. "Delitos de terrorismo (arts. 571, 572, 574, 576, 576 bis y 579)", en Comentarios a la reforma penal de 2010, Ed. Tirant lo Blanch, Valencia, 2010, p. 530 y 531.

27 GARCÍA ALBERO, R. "La reforma de los delitos de terrorismo", en $L a$ reforma penal de 2010: análisis y comentarios. Ed. Aranzadi. Cizur Menor, 2010, p. 371. 
en vigor $^{28}$. Unos procedimientos que han sido muy publicitados por los medios de comunicación, entre otras razones, porque en muchos supuestos han estado referidos a conductas tan aparentemente inofensivas que su persecución penal ha sido vista con cierto asombro, cuando no como algo incluso "pintoresco" (como sucedió, por ejemplo, con el procesamiento abierto respecto al conocido caso de los denominados "titiriteros de ETA" ${ }^{\prime 29}$ ), lo que, sin embargo, no ha impedido que en algunos de dichos procesos hayan terminado llevando, por desgracia y como parecía irremediable, a la emisión de alguna cuestionada, cuestionable y desgraciadamente celebre sentencia condenatoria para quienes tuvieron la desgracia de verse envueltos en los mismos.

28 MIRA BENAVENT, J. quien señala que la amplitud del tipo analizado y la tendencia jurisprudencial a no interpretarlo de forma restrictiva, han llevado a que no se aplique ya exclusivamente a los entornos de apoyo ideológico directo al terrorismo, sino también a personas que nade tienen que ver con dichos entornos no con las organizaciones o grupos terroristas, lo que ha determinado que el número de procedimientos abiertos por este delito por la AN se hayan cuadruplicado en menos de un año. Op. cit. ant. p. 320; mientras que MIRÓ LLINARES, F. indica como posible causa del notablemente el número de procedimientos relativos este delito la popularización del uso de Twitter, $O p$. cit. ant. p. 25, en nota al pie 14.

29 El caso enjuiciaba la conducta de unos titiriteros que representaron en Madrid una obra titulada "la bruja y San Cristobal", en la que, entre otras cosas, se representaba el ahorcamiento de un juez, mientras que a otro de los personajes (la bruja), víctima de un apaleamiento policial, la policía le colocaba una pancarta en la que se podía leer "Gora ALKA-ETA", con el fin de justificar su maltrato. Este supuesto de hecho que fue inicialmente investigado por poder constituir un supuesto de enaltecimiento terroristas, fue finamente sobreseído mediante auto de la Audiencia Nacional de 28 de junio de 2016, pues consideró que el uso de dicha pancarta no se realizó con el ánimo de enaltecer o alabar la conducta de las organizaciones criminales a las que hacía referencia (ETA y AL QAEDA), lo que llevaba a que no se pudiese apreciar el dolo del delito del art. $578 \mathrm{CP}$. Muy crítico con la persecución de estas conductas; se muestra PORTILLA CONTRERAS, G. quien la consideró “...uno de los mayores ataques a libertad de expresión que se recuerdan en España", en "El retorno de la censura y la caza de brujas anarquistas", en Cometer delitos en 140 caracteres. El Derecho penal ante el odio y la radicalización en Internet, Ed. Marcial Pons. Madrid, 2017, p. 88. 
Estamos, por tanto, ante un tema abierto y precisamente por ello, toca ahora concretar, con algo más de detenimiento, los difusos límites que definen los discursos prohibidos por esta controvertida figura delictiva. Esto es, la del delito o, mejor dicho, los delitos contemplados en el art. $578 \mathrm{CP}$, tarea que se ha de acometer para poder adoptar postura respecto a la posible compatibilidad de su prohibición penal con el necesario respeto y garantía de los derechos fundamentales protegidos por la constitución y que nos obliga tener que prestar especial atención a la interesante evolución que ha seguido nuestra jurisprudencia precisamente a la hora de tratar de interpretar estos delitos de una forma que resulte acorde con el necesario respecto a los derechos fundamentales de los ciudadanos que su existencia parece poner en tela de juicio.

\section{La controvertida delimitación de los discursos de odio sancionados por los delitos del art. $578 \mathrm{CP}$}

Resulta imposible analizar ahora con todo detalle todas y cada una de las propuestas realizadas en relación a la interpretación y delimitación de los delitos contemplados en el art. $578 \mathrm{CP}$ tendentes a compatibilizar los amplios contornos de las prohibiciones que le son inherentes con el necesario respeto y garantía del derecho a la libertad de opinión y de expresión de los ciudadanos. Sin embargo, creemos que todas ellas se pueden resumir y agrupar, a grandes rasgos, en dos líneas claramente diferenciadas. Dos tendencias que, además, han encontrado un eco significativo en las distintas resoluciones que han ido emitiendo nuestros tribunales con respecto a la aplicación de estas figuras.

Por una parte, estaría aquella corriente que considera que estos tipos delictivos castigan y persiguen determinados discursos intolerantes o de odio que generan un sentimiento de repulsa o rechazo social mayoritario y que, por ello, dan lugar a una sensación general de inseguridad colectiva que afecta a un bien jurídico instrumental y de titularidad colectiva como es la "paz pública", lo que convertirá a este valor en el verdadero bien ju- 
rídico protegido por estas figuras. Por otra y en clara contraposición con la anterior, se encontraría aquella línea de pensamiento que defiende que estos delitos solo será legítimos y se podrán aplicar en la medida en que se limiten a sancionar la difusión de aquellos discursos que actúen como idóneos instrumentos favorecedores o incitadores de la comisión general de futuros, aunque todavía no definidos ni concretados, actos terroristas por parte de sus posibles receptores, lo que convertiría a estas figuras en delitos que no castigarían los discursos enaltecedores, justificadores o humillantes de los que habla por el mero hecho de que fuesen rechazados o generasen un sentimiento de repulsa o inseguridad en la sociedad en general, sino porque actuarían como peligrosos instrumentos de incitación indirecta de ataques terroristas a una amplia y variada gama de posibles bienes jurídicos ${ }^{30}$.

Las repercusiones prácticas de sostener una u otra postura son evidentes.

La primera determinaría que nos encontrásemos ante delitos de conducta que sancionarían la emisión de determinados mensajes que no son realmente lesivos de bienes jurídicos individuales, sino que se prohíben y condenan por representar una ofensa y una lesión de los sentimientos o a la moral colectiva y de los valores más básicos de las sociedades democráticas (la tolerancia, la igualdad, etc...), con lo que su emisión resultaría siempre radicalmente ilegítima y podría ser, por ello, legítimamente prohibida y sancionada incluso mediante la utilización del Derecho penal ${ }^{31}$. La segunda, por su parte, mantiene que los

30 Sobre las diferentes propuestas realizadas a la hora de definir los delitos de odio y de justificar su legitimidad, véase, FUENTES OSORIO, J. L. "Concepto de "odio y sus consecuencias penales", en Cometer delitos en 140 caracteres. El Derecho penal ante el odio y la radicalización en Internet. Ed. Marcial Pons. Madrid, 2017, p. 133 y ss.

31 En esta línea, por ejemplo, MIRÓ LLINARES, F. quien señala que estos delitos no criminalizan la causación de un daño, ni siquiera remoto a bienes jurídicos individuales, sino ofensas a la moral colectiva. $O p$. cit. ant. p. 38 y 42 . 
mensajes de justificación o alabanza del terrorismo y de los terroristas o los de humillación o desprecio a sus víctimas, por muy despreciables que puedan parecer a la mayor parte de la sociedad, no podrían ser prohibidos ni castigados penalmente en tanto en cuanto no se constate que resultaban idóneos para provocar la futura comisión de delitos contra terceros, ya que solo así se apreciará aquella lesividad que legitimaría la prohibición y sanción penales de su difusión y la consecuente limitación del derecho fundamental a la libertad de expresión que éstas acarrearían ${ }^{32}$.

Ambas posturas, como se puede comprobar, aparecen claramente enfrentadas y ambas, como ya hemos adelantado, han ido encontrado eco en las diferentes resoluciones emitidas por nuestros Tribunales con relación al delito comentado. Unas resoluciones que, de hecho, se pueden agrupar, a nuestro modo de ver, en dos periodos temporales claramente diferenciados cada uno de los cuales responde, precisamente, al mantenimiento jurisprudencial mayoritario de una u otra postura y que quedan claramente separados por la emisión de la, como veremos, decisiva sentencia 112/2016, de 20 de junio de nuestro Tribunal Constitucional $^{33}$.

32 En relación a esta posible interpretación y a los motivos que llevan a sus defensores a mantenerla, véase, por ejemplo, lo comentado a este respecto por MIRA BENAVENT, J. quien, entre otras cosas, aludía a lo establecido por la Directiva 2017/541, del Parlamento Europeo y del Consejo, de 15 de marzo de 2017, y en concreto a su considerando $\mathrm{n}^{\circ} 10$ como fuente de respaldo de la necesidad de exigir que los actos castigados por estos delitos deban generar el peligro de posible comisión de otros actos terroristas, dado que de lo contrario esta figura se convertiría en un mero delito de opinión y por ello sería manifiestamente inconstitucional. Op. cit. ant. p. 317 y 318 .

33 Evidentemente, resulta imposible analizar en estas páginas con detalle toda la numerosa y controvertida jurisprudencia emitida por nuestros tribunales con respecto a esta figura, por lo que nos hemos decidido a agruparlas seleccionando tan solo algunas de las más recientes y que, a nuestro modo de ver, han tenido mayor repercusión. Para una visión más exhaustiva de la evolución jurisprudencial y de las diferentes opiniones adoptadas por nuestro tribunales a lo largo del tiempo con respecto a este delito, véase, por ejemplo, ALONSO RIMO, A. "Apología, enaltecimiento del terrorismo y 
Veamos a continuación ambos periodos y los efectos que ha tenido la evolución jurisprudencial producida en la aplicación del delito que nos ocupa.

\subsection{El discurso del odio terrorista como discurso con- tra los sentimientos generales}

Durante el primero de los periodos de los que hablamos en el epígrafe precedente, nuestra jurisprudencia se decantó claramente por mantener la primera de las posturas allí comentadas, dando lugar a un sinfín de muy comentadas y criticadas sentencias.

Entre ellas, alcanzaron especial repercusión social las referidas a los casos de Cesar Strawberry (STS 4/2017, de 18 de enero) y de Cassandra Vera (STAN 9/2017, de 23 de marzo).

En la primera de las referidas sentencias, el Tribunal Supremo enjuició el recurso de casación planteado frente a la sentencia absolutoria por delito de enaltecimiento del terrorismo y humillación de las víctimas emitida por la Audiencia Nacional ${ }^{34}$ respecto a las actividades que había realizado el rapero Cesar Strawberry, -miembro, entre otros, del conocido grupo Def con dos-, quien había publicado en su cuenta de Twitter, entre otros, comentarios como "el fascismo sin complejos de Aguirre me hace añorar hasta los GRAPO”, "a Ortega Lara habría que secuestrarle ahora" o "Cuántos deberían seguir el vuelo de Carrero Blanco",.

El Tribunal Supremo comenzó su sentencia relativa a este caso afirmando "...hemos de apartarnos de la tentación de construir el juicio de tipicidad trazando una convencional y ar-

principios penales", en RDPC, n 4, 2010, p. 39 y ss; CUERDA ARNAU, M. L. "Terrorismo y libertades políticas", disponible en https://core.ac.uk/ download/pdf/61388140.pdf (últ. vis. 18-9-2018) p. 33 y ss; BERNAL DEL CASTILLO, J. "El enaltecimiento del terrorismo y la humillación de sus víctimas..." cit. ant. p. 20 y ss o MIRÓ LLINARES, F. Op. cit. ant. p. 32 y ss, entre otros.

34 STAN 20/2016, de 18 de julio. 
tificiosa línea entre el discurso del odio y la ética del discurso"; realizando a continuación una afirmación que no por obvia, debe ser menospreciada al señalar que "...El derecho penal no puede prohibir el odio, no puede castigar al ciudadano que odia.".

De hecho, y, en esa misma línea, también apuntó que "Entre el odio que incita a la comisión de delitos, el odio que siembra la semilla del enfrentamiento y que erosiona los valores esenciales de la convivencia y el odio que se identifica con la animadversión o el resentimiento, existen matices que no pueden ser orillados por el juez penal con el argumento de que todo lo que no es acogible en la libertad de expresión resulta intolerable y, por ello, necesariamente delictivo."

Sin embargo, y tras este esperanzador comienzo, la sentencia ahora comentada, aludiendo a varios precedentes judiciales y, entre ellos, a sentencias del Tribunal europeo de Derechos Humanos, (p. ej. SSTEDH de 8 de julio de 1999, Sürek vs Turquía, 4 de diciembre de 2003, Müslüm vs Turquía), referidas a la legitimidad de la posible proscripción y sanción del discurso del odio y la compatibilidad de dicho castigo con el necesario respeto al derecho a libertad de expresión de los Estados democráticos, pasó a afirmar “...que la libertad ideológica o de expresión no pueden ofrecer cobijo a la exteriorización de expresiones que encierran un injustificable desprecio hacia las víctimas del terrorismo, hasta conllevar su humillación", ya que afirmaciones como las realizadas por el acusado, a juicio del Alto Tribunal “....alimentan el discurso del odio, legitiman el terrorismo como fórmula de solución de los conflictos sociales y, lo que es más importante, obligan a la víctima al recuerdo de la lacerante vivencia de la amenaza, el secuestro o el asesinato de un familiar cercano".

Todo ello llevó a nuestro Tribunal Supremo a afirmar que las manifestaciones realizadas por Cesar Strawberry no estaban amparadas por el derecho fundamental a la libertad de expresión, con lo que podían ser legítimamente castigadas por el Derecho penal, conforme a lo establecido en el delito del art. 578 
$\mathrm{CP}$; delito en cuyo tipo objetivo eran perfectamente subsumibles y cuyo tipo subjetivo en modo alguno exigía la existencia de una especial finalidad de apoyo al terrorismo o de humillación a sus víctimas en su autor para poder castigarle por su realización, sino simplemente que tuviese consciencia de que el acto que realizaba era objetivamente enaltecedor o humillante, por lo que, contra el criterio inicialmente absolutorio mantenido sentencia de la Audiencia Nacional, la Sala del Supremo terminó condenando a César Strawberry a una pena de 1 año de prisión, con 6 años y 6 meses de inhabilitación absoluta por la comisión del referido delito.

Como se puede comprobar, en ningún momento de la sentencia exigió para apreciar este delito que el mensaje que se tratase de subsumir en el mismo presentase alguna idoneidad incitadora para fundamentar el castigo que dicha figura preveía por su emisión. La resolución se limitó a encajar el discurso emitido por el acusado en el discurso del odio del que hablaba el tipo (el enaltecedor o justificador del terrorismo o el humillante para las víctimas), para a reglón seguido afirmar que con que el sujeto que lo emitiese conociese que el mensaje que transmitía presentaba dichos caracteres se le podría y debería castigar por la comisión del delito del art. 578 de nuestro Código penal.

Con ello, el Tribunal Supremo adoptó una postura claramente favorable a entender que este delito, cuando menos en su modalidad de humillación a las víctimas, castigaba, como expresamente reconocía, aquel discurso del odio "...que erosiona los valores esenciales de la convivencia" y no necesaria y exclusivamente el "...que incita a la comisión de delitos", en lo que suponía un evidente respaldo a la primera de las líneas interpretativas anteriormente comentadas referidas a este delito.

Algo parecido sucedió en el caso de la sentencia de la Audiencia Nacional 9/2017, de 23 de marzo, emitida en el denominado caso "Casandra". La acusada en este procedimiento publicó en su cuenta de Twitter comentarios supuestamente jocosos referidos al asesinato en los años setenta, a manos de ETA 
del Almirante Carrero Blanco, quien en el momento del atentado era presidente del gobierno franquista. Así, por ejemplo, se podían ver en su cuenta de dicha red social frases referidas a dicho atentado como "ETA impulsó una política contra los coches oficiales combinada con un programa espacial", "Kissinger le regaló a Carrero un trozo de la luna, ETA le pagó el viaje a ella", “Carrero también regresó al futuro con su coche?”, junto a otros contenidos como la imagen de un astronauta con la cara del Almirante, en lo que parecía ser la superficie lunar con la bandera de España de la dictadura, escudo preconstitucional con águila incluida, a lo que añadió siguiente la expresión: “20D”, fecha del atentado que éste sufrió.

La sentencia de la Audiencia Nacional partió de señalar que la propia Exposición de Motivos de la LO 7/2000 que introdujo el delito de enaltecimiento del terrorismo y humillación de las víctimas señalaba, como ya vimos, que su creación vendría a castigar los actos denigratorios de estas últimas por "... la perplejidad e indignación que generaban en la sociedad”, circunstancia ésta que fue, a juicio del Tribunal, la que precisamente llevó al legislador a dar a dicha clase de manifestaciones de discurso del odio, que socavan las bases de la convivencia y humillaban a las víctimas, el tratamiento específico que le otorgaba el art. 578 CP. Este delito, por ello y según afirmaba la comentada sentencia, castigará todos los actos de humillación de las víctimas, ya que tales actos nunca podrían estar amparados por el derecho a la libertad de expresión, sin que se necesite para castigarlos que los mensajes humillantes de los que habla se difundan con finalidad específica alguna, sino simplemente con la consciencia de que su contenido podía humillar o vejar a dichos sujetos, con lo que resultaba del todo irrelevante que en el caso enjuiciado se hubiesen difundido con finalidad humorística o jocosa y no con la de humillar a nadie o la de respaldar o no al terrorismo.

La cercanía de la argumentación mantenida por la $\mathrm{Au}-$ diencia Nacional con la de la sentencia anteriormente comentada del Tribunal Supremo y, por tanto, también con la primera de 
las líneas interpretativas referidas al art. $578 \mathrm{CP}$ resulta evidente, por lo que no puede sorprender que esta resolución concluyese, de forma similar a como lo hacía aquélla, condenando a la acusada a una pena de un año de prisión, con la accesoria de inhabilitación especial para el ejercicio del derecho de sufragio pasivo por tiempo de un año, e inhabilitación absoluta durante siete años.

Sin embargo, y como ya dijimos no ha sido ésta la única línea interpretativa que ha encontrado respaldo por parte de nuestros tribunales. También la otra propuesta interpretadora referida al $578 \mathrm{CP}$ ha tenido eco en nuestra jurisprudencia, sobretodo, tras la emisión por parte de nuestro Tribunal Constitucional de la, a nuestro modo de ver decisiva, Sentencia 112/2016, de 20 de junio $^{35}$.

\section{2. El discurso del odio terrorista como discurso in- citador de delitos}

En la sentencia anteriormente citada de nuestro Tribunal Constitucional (la 112/2016, de 20 de junio), se analizaba el recurso de amparo interpuesto por Tasio Erkizia Almandoz contra la condena por delito de enaltecimiento del terrorismo que se

35 En tal sentido, destaca ALCACER GUIRAO, R. que dicha sentencia fue, precisamente, la primera en que el TC abordó la cuestionada constitucionalidad del delito de enaltecimiento del terrorismo, en Op. cit. ant. p. 2; aunque bien es cierto que dicho Tribunal ya había tenido ocasión de manifestarse en una ocasión anterior con respecto a este delito. En concreto, lo hizo en el Auto 4/2008, de 9 de enero, en el que, citando expresamente la sentencia previa 235/2007 del alto Tribunal, se inadmitió el recurso de amparo planteado, por considerar que el castigo del recurrente por un delito de justificación del terrorismo no violaba el derecho fundamental a la libertad de expresión, ya que, al haber afirmado el condenado en un escrito titulado "El Escudo", que la lucha de los presos terroristas estaba cargada de razón y por ello, éstos resistían los intentos resocializadores que se realizaban en prisión, al tiempo que señalaba que si no se sacaba las manos de Euskal Herria, se terminaría por perderlas, se trasmitía un mensaje justificador de las conductas terroristas y amenazante que incitaba indirectamente a volver a cometerlas, algo que, como había señalado, la STS 235/2007, no quedaría amparado por el referido derecho fundamental. 
le había impuesto por haber participado como orador principal en un acto público de homenaje que se había realizado en Arrigorriaga (Vizcaya) en recuerdo del conocido dirigente de ETA, José Miguel Beñaran Ordeñana, alias 'Argala', quien había sido asesinado treinta años antes en Angilu (Francia) por miembros del denominado Batallón Vasco Español.

En dicho acto, presidido por una foto del terrorista homenajeado ante la cual bailaron dantzaris' que ejecutaron una 'Ezpatadantza' o danza de espadas, (baile de conmemoración y rendición de honores en el que los bailarines saludan con espadas de forma similar a la presentación de armas de los actos militares), el acusado, tras depositar flores ante la referida foto, dio un discurso de cierre en el que, tras pedir que se hiciese “'una reflexión [para] escoger el camino más idóneo, el camino que más daño le haga al Estado, que conduzca a este pueblo a un nuevo escenario democrático'" concluyó lanzado gritos de ";Gora Euskal Herria askatuta', 'Gora Euskal Herria euskalduna'y 'Gora Argala. '-;Viva Euskal Herria libre! ;Viva Euskal Herria vasca! ;Viva Argala. !, gritos que fueron respondidos por el público"

Dicha actuación fue considerada por la Audiencia Nacional como constitutiva de un delito de enaltecimiento del terrorismo, postura que fue posteriormente refrendada por el Tribunal Supremo en su Sentencia 180/2012, de 14 de marzo, en la que, tras afirmarse la legitimidad constitucional del delito del art. 578 $\mathrm{CP}$, precisamente, por considerarse que venía a castigar una forma del discurso del odio, cuya prohibición y sanción penales habían sido consideradas como legítimas por el TEDH y el propio TC español en otros casos, se señalaba que la finalidad de este delito era “...combatir la actuación dirigida a la promoción pública de quienes ocasionan un grave quebranto en el régimen de libertades y en la paz de la comunidad con sus actos criminales, abortando toda clase de justificación y apoyo para lo que no son sino cumplidos atentados contra la significación más profunda del propio sistema democrático", postura ésta que, como se puede comprobar, fundamenta la condena del acusado, de nuevo, en 
una interpretación del artículo $578 \mathrm{CP}$ acorde con la ya sostenida en las sentencias que comentamos en el epígrafe anterior.

Frente a ello, nuestro Tribunal Constitucional recordó que el derecho a la libertad de expresión no vale solo para “...la difusión de ideas u opiniones "acogidas con favor_o consideradas inofensivas o indiferentes, sino también para aquellas que contrarian, chocan o inquietan al Estado o a una parte cualquiera de la población», ya que en nuestro sistema "no tiene cabida un modelo de 'democracia militante', esto es, un modelo en el que se imponga, no ya el respeto, sino la adhesión positiva al ordenamiento $y$, en primer lugar, a la Constitución". De hecho, afirmaba nuestro Tribunal Constitucional en la sentencia analizada "...El valor del pluralismo y la necesidad del libre intercambio de ideas como sustrato del sistema democrático representativo impiden cualquier actividad de los poderes públicos tendente a controlar, seleccionar, o determinar gravemente la mera circulación pública de ideas o doctrinas".

Sin embargo, señalaba el máximo intérprete constitucional, continuando con su argumentación, lo anterior no puede, ni debe llevarnos a pensar que la libertad de expresión sea un derecho ilimitado. Dicha libertad, como cualquier otro derecho fundamental, se puede limitar y restringir cuando entre en conflicto con otros derechos e intereses legítimos. El problema entonces estaría en delimitar qué discursos o mensajes, por muy reprochables moral o socialmente que puedan resultar, continuarían estando amparados por dicho derecho fundamental y cuáles, por el contrario, supondrían tal ataque a otros valores legítimos que serán susceptibles de ser prohibidos e sancionados por el legislador incluso mediante el uso del Derecho penal ${ }^{36}$.

36 ROLLNER LIERN, G. destaca, precisamente en relación a este tema, la, a su modo de ver, contradictoria argumentación mantenida por el Tribunal constitucionalidad a la hora de analizar el conflicto que genera la prohibición del discurso del odio con la libertad de expresión, ya que, si bien en algunas ocasiones el TC parece considerar dicha clase de discursos como abusos y usos ilegítimos de la libertad de expresión, lo que legitimaría la 
Precisamente, para responder a esta cuestión nuestro Tribunal Constitucional acudió a la argumentación que ya había empleado en una sentencia previa referida a la posible legitimidad del castigo de ciertos discursos calificados como "de odio". En concreto, a lo que ya había manifestado en la STC 235/2007, de 7 de noviembre, relativa al delito de negación y justificación del genocidio, donde afirmó que lo que legitimaría la prohibición y sanción de los discursos de los que dicho delito hablaba era, precisamente, que tales expresiones podían generar un clima hostil contra determinados colectivos que actuaría como instrumento de promoción o incitación indirecta de la comisión del delito que justificaban o negaban, (el genocidio), contra sus integrantes. De este modo, habrá que pasar a considerar a esta figura como un ejemplo de lo que se ha venido a denominar como "delitos de clima"; unos delitos que castigan una modalidad de incitación indirecta de tal delito, incitación que, sin embargo y a

proporcionada restricción de ésta libertad que ocasionaría su prohibición y castigo, en otras, parece entender tales discursos como completamente ajenos al ámbito de protección de la libertad de expresión, en "El discurso del odio y los límites de a libertad de expresión: de "la zona intermedia" a los estándares internacionales", en Cometer delitos en 140 caracteres. El Derecho penal ante el odio y la radicalización en Internet. Ed. Marcial Pons. Madrid, 2017, p. 257 y 258; postura que, a nuestro juicio, incurre en un equivoco, ya que, en realidad, lo que hace el TC en esta sentencia no es analizar si la prohibición del discurso de odio limita desproporcionadamente la libertad de expresión de los ciudadanos, algo que ya había afirmado en repetidas sentencias anteriores y había sido previamente ratificado por los Tribunales internacionales como el TEDH, sino definir y delimitar qué clase de discurso de apoyo terrorista puede ser considerado como "de odio", abriéndose así las puertas a su posible persecución penal por no poder entenderse amparada su difusión por la libertad de expresión. Dicho en otros términos, nuestro máximo intérprete constitucional no analiza la cuestión relativa a la posible proporcionalidad de la prohibición de los discursos de odio, porque ya la había afirmado anteriormente. Lo que analiza es si y en qué medida los concretos mensajes prohibidos por el delito del art. $578 \mathrm{CP}$ pueden ser considerados como manifestaciones de discursos de odio y por ello pueden ser castigados penalmente, ya que, de lo contrario, esto es, si no lo fuesen, por muy desagradables que nos pudieran parecer estarían amparados por la libertad de expresión y, por tanto, su comunicación o difusión nunca podría constituir delito. 
juicio del TC, no se podría apreciar ni siquiera de forma implícita en los discursos meramente negacionistas que prohibía, lo que fundamentó que se calificase a la prohibición penal de esta última clase de discursos de inconstitucional ${ }^{37}$.

Trasladando dichas premisas al delito del art. $578 \mathrm{CP}$, afirmó nuestro Tribunal Constitucional, en su ya citada STC $112 / 2016$, que, para que los mensajes de los hablan las figuras

37 En concreto, se trata de la Sentencia del Tribunal Constitucional de 7 de noviembre de 2007 , relativa a la constitucionalidad del delito de negacionismo y justificación del genocidio del, en aquel entonces vigente, art. 607 $\mathrm{CP}$; sentencia en la que, si bien se declaró la inconstitucionalidad del castigo del negacionismo como tal, sí que se admitió la compatibilidad con la Carta Magna de aquella parte del comentado delito que castigaba la justificación del delito de genocidio, precisamente porque la manifestación acorde o la valoración positiva de la realización de tan terrible conducta delictiva presenta un elemento tendencial de creación de un clima social de hostilidad que podría incitar indirectamente a una nueva ejecución de tan odioso delito; delimitación que, por ejemplo, a juicio de RAMOS VÁZQUEZ, J. A. podría transponerse al delito de enaltecimiento y justificación del terrorismo, convirtiéndolo en un delito de clima que indirectamente incitaría a cometer delitos de dicha naturaleza, en $O p$. cit. ant. p. 788 y ss y 799 y ss. Sobre el origen y desarrollo de esta corriente jurisprudencial que hunde sus raíces en la evolución de la jurisprudencia emanada del Tribunal Europeo de Derechos Humanos y, en concreto de la interpretación que dicho Tribunal ha realizado del art. 10 del CEDH en relación con el art. 17 de dicho convenio, para permitir la prohibición de los discursos de odio, véase, RODRÍGUEZ MONTAÑÉS, T. Op. cit. ant. p. 221 y ss. Sobre el origen dogmático de esta categoría de delitos y su posible aplicación a otros delitos de nuestro Código penal, como el contenido en el art. 510 CP, véase, lo comentado por GÓMEZ MARTÍN, V. "Discurso del odio y principio del hecho" en Protección penal de la libertad de expresión e información. Una interpretación constitucional. Ed. Tirant lo Blanch, Valencia, 2012, p. 89 y ss. Crítico, por otra parte, con la delimitación del esta clase de delitos realizada por el TC en la sentencia comentada se manifiesta ALCACER GUIRAO, R., precisamente, por entender que la delimitación que de los mismos hizo la comentada Sentencia como delito de clima ha permitido legitimar la existencia de delitos (como el de injurias a la corona) que realmente poco o nada tienen que ver con el verdadero origen conceptual de dicha categoría destinada a proteger a colectivos vulnerables o discriminados. En Op. cit. ant. p. 7 y ss. También crítica con esta sentencia se manifiesta CUERDA ARNAU, M. L. Op. cit. ant. p. 33 y ss. 
contempladas en dicho precepto puedan ser considerados como formas específicas del discurso del odio no amparados por el derecho a la libertad de expresión será necesario que con su emisión se aprecie “...una situación de riesgo para las personas o derechos de terceros o para el propio sistema de libertades”, ya que ello sería una condición necesaria para que su prohibición y sanción penal pueda resultar acorde y ajustada “...para con el estándar del derecho de la libertad de expresión por ser necesaria esa injerencia en una sociedad democrática también aparece en el contexto internacional y regional europeo".

Se decantó así el Tribunal Constitucional por exigir la constatación de la generación de un riesgo de comisión de delitos como consecuencia de la difusión de los mensajes de los que habla el art. $578 \mathrm{CP}$, para poder tener su castigo y prohibición penales como acordes a nuestra Constitución, en lo que supuso un claro posicionamiento en favor de entender esta figura como un delito de peligro para los intereses individuales de terceros y no como uno que simplemente protegiese los sentimientos colectivos de la sociedad, por muy legítimos y loables que dichos sentimientos pudiesen $\operatorname{ser}^{38}$.

Pese a ello, la Sala, (aunque con el voto discrepante del Magistrado Juan Antonio Xiol Ríos ${ }^{39}$ ), ratificó la sentencia condenatoria del solicitante de amparo, precisamente, por entender

38 De hecho y en este sentido, se afirma en el Fundamento Jurídico 4 de la citada sentencia que “...el art. 578-«el enaltecimiento o la justificación por cualquier medio de expresión pública o difusión de los delitos comprendidos en los artículos 571 a 577 de este Código [delitos de terrorismo] o de quienes hayan participado en su ejecución»-supone una legítima injerencia en el ámbito de la libertad de expresión de sus autores en la medida en que puedan ser consideradas como una manifestación del discurso del odio por propiciar o alentar, aunque sea de manera indirecta, una situación de riesgo para las personas o derechos de terceros o para el propio sistema de libertades."

39 En concreto, en su interesante voto, el Juan Antonio Xiol Ríos señalaba que para apreciar delito del art. $578 \mathrm{CP}$ se requería que la conducta realizada, “...más allá del estricto cumplimiento de los elementos objetivos y subjetivos del delito de enaltecimiento del terrorismo, suponga una incitación, 
que, teniendo en cuenta sus manifestaciones, los medios que se habían empleado para realizarlas y el contexto social en el que las había efectuado, se podía apreciar la presencia de un acto de instigación a la violencia, afirmando en tal sentido que “... incitar supone siempre llevar a cabo una acción que ex ante implique elevar el riesgo de que se produzca tal conducta violenta. Desde esta última perspectiva, acciones como las que nos ocupan crean un determinado caldo de cultivo, una atmosfera o ambiente social proclive a acciones terroristas, antesala del delito mismo, singularmente si se tienen en cuenta las circunstancias en las que cursaron los hechos: fue un acto público, previamente publicitado mediante carteles pegados en las calles, en un contexto en el que la actividad terrorista seguía siendo un importante problema social. Por consiguiente, es incuestionable que, para un espectador objetivo, la conducta del recurrente era idónea para contribuir a perpetuar una situación de violencia." (la negrita es nuestra).

La incidencia de esta sentencia no tardó en hacerse sentir en la jurisprudencia del Tribunal Supremo, dando lugar un cambio significativo en la línea jurisprudencial que hasta aquel entonces dicho Tribunal había mantenido.

Una de las muestras más evidentes de este cambio de rumbo se produjo precisamente en la Sentencia 95/2018, de 26 de febrero, que emitió el Tribunal Supremo respecto al recurso de casación presentado en el ya comentado caso de Cassandra Vera.

Como vimos, dicho caso versaba sobre la difusión en una conocida red social (Twitter) de mensajes burlescos sobre el asesinato terrorista del Almirante Carrero Blanco, lo que determinó que la autora de la difusión de tales mensajes (Cassandra Vera)

aunque sea indirecta, a la violencia terrorista. "; elemento éste último que no apreció en el hecho en cuestión, dado que, en realidad, las afirmaciones realizadas por el acusado estaban más orientadas a fomentar el debate sobre el fin de la violencia que en promoverla, habiendo sido condenado, a su modo de ver, por expresiones que, si bien se habían producido en el acto en que tomó parte, no se pudo demostrar que hubiesen sido efectuadas por él. 
fuera condenada por la Audiencia Nacional, en primera instancia, por la realización de un delito del art. $578 \mathrm{CP}$ en su modalidad de humillación de las víctimas del terrorismo.

Lo primero que hizo el Tribunal Supremo en la sentencia referida a este caso, en clara contradicción con la postura que había mantenido en resoluciones anteriores, fue señalar que el Derecho penal no puede castigar ni perseguir comentarios o ideas simplemente porque provoquen la indignación o el rechazo de la mayoría de la sociedad; posicionamiento que contrastaba, como se puede comprobar, con muchos de los que la Sala había mantenido con anterioridad. Justo a continuación y entrando ya en el análisis del caso concretamente enjuiciado, señaló la Sala que debía tenerse en cuenta que las mofas realizadas por la acusada no estaban referidas a la víctima del atentado terrorista como persona, sino a la forma en que dicho atentado se produjo y, además, se referían y burlaban de algo que había “... tenido lugar hace ya 44 años, tiempo más que suficiente para considerarlo como un suceso histórico cuyo comentario en clave de humor no puede tener la misma transcendencia que un acontecimiento reciente".

Partiendo de estas bases y citando expresamente a la STC 112/2016, nuestro Tribunal Supremo afirmó que para que el delito del art. $578 \mathrm{CP}$ pueda castigar legítimamente una expresión humillante de las víctimas o enaltecedora del terrorismo “... requiere, como una manifestación del discurso del odio, una situación de riesgo para las personas o derechos de terceros o para el propio sistema de libertades como condición para justificar su compatibilidad con el estándar del derecho de la libertad de expresión"; exigencia ésta que, por otra parte, el Alto Tribunal consideraba plenamente coherente con lo manifestado en la reciente Directiva europea (UE) 2017/541, relativa a la lucha contra el terrorismo que había venido a sustituir a la anterior Decisión Marco 2002/474/JAI, cuyo considerando 10 señala que "Los delitos de provocación pública a la comisión de un delito de terrorismo comprenden, entre otros, la apología y la justificación del terrorismo o la difusión de mensajes o imágenes, ya sea en línea o no, entre ellas las relacionadas con las víctimas del 
terrorismo, con objeto de obtener apoyo para causas terroristas o de intimidar gravemente a la población", afirmando, justo a continuación y de forma expresa, que "Esta conducta debe tipificarse cuando conlleve el riesgo de que puedan cometerse actos terroristas.", lo que obligaba, según el propio regulador comunitario, a analizar cada uno de esos mensajes teniendo “... en cuenta las circunstancias especificas del caso, como el autor y el destinatario del mensaje, así como el contexto en el que se haya cometido el acto. También deben considerarse la importancia y la verosimilitud del riesgo al aplicar la disposición sobre provocación pública de acuerdo con el Derecho nacional»" (la negrita es nuestra).

Se decantó de esta forma, el Alto Tribunal, de forma acorde con lo sostenido por el TC con antelación, por interpretar el delito del art. $578 \mathrm{CP}$ como un delito de peligro, cuya realización solo se podrá apreciar cuando los mensajes de los que habla generen un riesgo real de incitar a sus posibles destinatarios a cometer futuros delitos terroristas; elemento éste que no entendió que concurriese en la concreta actuación realizada por Cassandra Vera, lo que le llevó a absolverla del comentado delito, por considerar que la acusada "...ni dio muestras con su conducta de que estaba pretendiendo incitar a la violencia abusando de un ejercicio ilícito de la libertad de expresión, ni provocaba al odio hacia grupos determinados, ni tampoco se valía de mofarse del atentado contra un expresidente de Gobierno ocurrido hace más de cuarenta años con intención de justificarlo o de incitar a nuevos atentados".

Como se puede comprobar el cambio del fundamento delimitador del injusto típico castigado en el delito del art. 578 $\mathrm{CP}$, de uno sustentado en la mera lesión de la paz pública o de los sentimientos generales de la sociedad a otro basado en la presencia o generación de un peligro real de incitación de la comisión de nuevos delitos terroristas, determinó que se hiciese una interpretación restrictiva de los mensajes que podrían llegar a alcanzar relevancia típica conforme al referido precepto, en su modalidad de humillación de las víctimas, y a que se absolviese 
a una persona que había sido previamente condenada atendiendo a los parámetros interpretativos alternativos referidos a dicho delito que el propio Tribunal Supremo había sostenido en resoluciones anteriores.

Ahora bien, no ha sido ésta la primera ni la única resolución judicial que ha adoptado este cambio radical de postura. De hecho, la interpretación ahora comentada ya había tenido reflejo, por ejemplo, en otra sentencia previa de nuestro Tribunal Supremo. Se trata de la STS 52/2018, de 31 enero, referida al caso del twittero Arkaitz Terrón. En esta resolución se enjuiciaba el hecho de que el acusado hubiese publicado desde su cuenta de Twitter, entre otros mensajes, algunos como "Roma acoge este sábado una cumbre de la extrema derecha [...] Estando ahi juntitos... Un 'Carrero'no estaría mal”, "Juan Carlos Primero, más alto que Carrero!!"; "Entonces, ¿Mañana hace el saque de honor Irene Villa?", en alusión a una de las más conocidas víctimas del terrorismo etarra y otras como aquella que, tras la muerte en la cárcel del conocido terrorista Arkaitz, decía "Adiós y honor, Arkaitz Siempre en el recuerdo".

Ya en primera instancia, la Audiencia Nacional había afirmado en su sentencia 12/2017, de 21 de marzo, que las manifestaciones realizadas por el acusado no tendrían encaje en el delito del art. $578 \mathrm{CP}$, dado que dichos mensajes "no incitan o alientan ni instigan a la violencia terrorista, ni siquiera de forma indirecta, ni generan un peligro o riesgo de comisión de actos violentos". Esta postura fue severamente cuestionada por el Ministerio Fiscal en el recurso de casación que presentó contra dicha Sentencia, por entender que dicho posicionamiento jurisprudencial convertía “...el delito del art. $578 \mathrm{CP}$, que es de mera actividad, en un delito de resultado, en contra de la propia naturaleza jurídica del tipo penal y de la doctrina de la Sala $2^{a}$ del Tribunal Supremo"; una doctrina que, como expresamente recuerda el Ministerio Fiscal en su recurso, señalaba con respecto al tipo objetivo de este delito que "el enaltecimiento/justificación del art. 578 constituye una forma autónoma de apología caracterizada por su carácter genérico y sin integrar una 
provocación ni directa ni indirecta a la comisión de un delito. La barrera de protección se adelanta, exigiéndose solamente la mera alabanza/justificación genérica, bien de los actos terroristas o de quienes los efectuaron; y respecto del tipo subjetivo advierte de su distingo de la motivación o móvil del sujeto".

Precisamente y frente a este último planteamiento, señaló el Tribunal Supremo en la sentencia que finalmente emitió con respecto a dicho recurso de la Fiscalía, que debía tenerse en cuenta para dar una adecuada interpretación del referido delito, ésta debía ajustarse a lo manifestado en la tantas veces citada Sentencia 112/2016 del Tribunal Constitucional “...por cuanto en la referida sentencia, interpretativa de esta tipología, exige, para entender constitucionalmente legítima dicha injerencia legislativa en la libertad de expresión, algún tipo de incitación, aún cuando fuere indirecta."; exigencia que, a juicio del Alto Tribunal, determina que nos encontremos entonces ante un verdadero delito de aptitud, cuya tipicidad quedará excluida si no se constata, atendiendo a las concretas circunstancias del caso, la idoneidad del contenido difundido para incitar directa o indirectamente a sus receptores a cometer algún delito de terrorismo (no necesariamente uno concreto acotado en el tiempo o referido a concretas personas) y que, además, solo podrá aplicarse si se demuestra que quien lo transmitió abarcó en su dolo el riesgo que iba a generar al hacerlo.

La coincidencia de nuestro Tribunal Supremo con lo previamente manifestado en primera instancia fue, como se puede ver, total, lo que le llevó ratificar la absolución del comentado twittero por entender que sus mensajes no contenían “...llamamiento a la violencia terrorista ni han generado riesgo alguno para las personas, ni los derechos de terceros ni para el orden jurídico", entre otras cosas, porque no habían tenido impacto alguno en la opinión pública hasta que no fueron detectados por las investigaciones policiales.

Las respuestas a estas sentencia no se hicieron esperar, llegando, según parece, algunas eurodiputadas, víctimas del te- 
rrorismo de ETA, a pedir una reunión con alguno de sus ponentes para exponerle su desagrado con la resolución y decirle que había interpretado incorrectamente lo dispuesto en la Directiva europea antiterrorista anteriormente citada, en cuya redacción decían haber participado ${ }^{40}$.

Pese a todo, debe ponerse de manifiesto que esta segunda y más reciente interpretación jurisprudencial en modo alguno ha impedido que haya sentencias condenatorias por el delito del que nos venimos ocupando. De hecho, así ha sucedido, por ejemplo, en la STS 79/2018, de 15 de febrero, que ratificó la condena previamente emitida por la Audiencia Nacional del rapero Valtónyc, o en la STS 354/2017, de 17 mayo, referida a un caso de enaltecimiento del terrorismo yihadista.

En la primera de las referidas sentencias, se juzgaba al rapero conocido como Valtónyc por algunas de las expresiones utilizadas en sus canciones, entre las que se encontraban " $U n$ pistoletazo en la frente de tu jefe está justificado o siempre queda esperar a que le secuestre algún GRAPO”, "Dicen que pronto se traspasa la cloaca de Ortega Lara y muchos rumorean que Rubalcaba merece probarla, complejo de zulo mi casa a ver si un día secuestro alguno y le torturo mientras le leo al Argala”, “ Quiero transmitir a los españoles un mensaje de esperanza, ETA es una gran nación", "Matando a Carrero ETA estuvo genial, a la mierda la palabra, viva el amonal" o "Por qué condenáis la puta lucha armada, contra la clase que tiene a la nuestra esclavizada". Estas expresiones llevaron a la inicial condena de Valtónyc emitida por la Audiencia Nacional en su Sentencia 4/2017, de 21 de febrero, fuese ratificada por el Tribunal Supremo que, citando nuevamente de forma expresa la STC 122/2015, afirmó que para poder apreciar este delito se hacía necesario constatar la presencia de un riesgo de inducir a cometer delitos; riesgo que ha "...de entenderse en abstracto como «aptitud» insita en la actuación imputada, pero no referido a un concreto delito de te-

40 http://www.elmundo.es/espana/2018/02/09/5a7cbdb0e2704e4a2e8b45ba. html (últ. cons. 12-4-2018). 
rrorismo, acotado en tiempo, espacio, por referencia a personas

afectadas" y que se considera generado, en el caso enjuiciado como señalaba la precedente sentencia de la $\mathrm{AN}$, dado que las expresiones empleadas por el rapero tenían un "...carácter laudatorio de las organizaciones terroristas GRAPO y ETA y de sus miembros, el cual va más allá de la expresión de coincidencia con objetivos politicos, solidaridad con los presos o camaradería nacida de vínculos ideológicos y que comporta una alabanza, no ya de los objetivos políticos sino de los medios violentos empleados por la citadas organizaciones terroristas y por sus miembros y contienen una incitación a su reiteración. Los referidos contenidos no quedan amparados por la libertad de expresión o difusión de opiniones invocada por el acusado y su defensa" (la negrita es nuestra).

Por otra parte, entrando ya en el análisis de la segunda de las sentencias citadas, la STS 354/2017 de 17 mayo, hay que señalar que dicha resolución juzgó a un ciudadano extranjero que publicó, de forma reiterada, en su página de Facebook, vídeos e imágenes en los que se veía a musulmanes siendo golpeados, vejados y asesinados en diferentes lugares del mundo, a los que acompañaba con mensajes que culpabilizaban de tales hechos a los que calificaba como "infieles" (primordialmente judíos y musulmanes chiíes), con soflamas procedentes del discurso radical habitualmente empleado por el terrorismo yihadista y con mensajes que justificaban que los musulmanes actuasen como terroristas para defenderse de dichos ataques.

Frente a la versión sostenida por la defensa que afirmaba que lo único que hizo el acusado fue informar a la opinión pública de la situación que estaban sufriendo algunos musulmanes en el mundo, nuestro Tribunal Supremo entendió que, en realidad, junto a dichos actos informativos se incluían otros contenidos y mensajes que justificaban y legitimaban el uso de la violencia terrorista contra determinados colectivos para responder a tales ataques a los musulmanes, lo que daba lugar a la aparición del riesgo de incitación a la comisión de delitos por parte de los receptores de estos mensajes y, consecuentemente, al acto de 
inducción indirecta que legitima y configura el injusto propio del delito del art. $578 \mathrm{CP}$.

De hecho, se afirmaba en esta sentencia que en los mensajes analizados se podían apreciar perfectamente las cuatro etapas que caracterizan la técnica de marketing utilizada habitualmente por el discurso del odio yihadista como instrumento de incitación indirecta a la comisión de delitos. A saber, “...1) victimismo (el musulmán es una víctima); 2) culpabilización (identificación de grupos responsables); 3) solución ¿soy buen musulmán? ¿qué debo hacer?; y 4) activismo (justificación de la violencia)", lo que, sin duda, suponía un discurso implícitamente idóneo para inducir a llevar a cabo actos terroristas en general e incrementaba el riesgo de su comisión y, por ello, hacía que la conducta enjuiciada pudiese y debiese ser considerada como perfectamente sancionable conforme al delito del art. $578 \mathrm{CP}$.

\section{El delito de enaltecimiento, una figura al borde del abismo}

A lo largo de este trabajo hemos podido comprobar como la pretensión de afrontar el reto preventivo que plantea el terrorismo y especialmente el yihadista mediante la prohibición del discurso de intolerancia y odio que suele utilizar, ha llevado a nuestro legislador a crear muchas figuras delictivas y entre ellas algunas ciertamente controvertidas.

Sin duda, la enorme amplitud e incluso la indeterminación de algunos de estos nuevos delitos e instrumentos penales han llevado a que nuestro sistema se sitúe al borde, cuando no más allá, de las fronteras que delimitan el necesario respeto y garantía de los derechos a la libertad ideológica y de expresión que debe acatar todo Estado democrático que se quiera tener realmente por tal y no por un ejemplo de lo que se ha venido a llamar como "democracia autoritaria" o "democracia de carácter formal" y no material. ${ }^{41}$

41 En este sentido, señala MIRA BENAVET, J. que la reforma realizada por LO 2/2015 de los delitos de enaltecimiento “....constituye un indicio más 
Así sucedió, como ya vimos con mayor extensión en otro lugar, con el delito de adoctrinamiento activo relativo a la emisión de mensajes de apoyo o respaldo de las ideas o el discurso terrorista no directamente dirigidos a fomentar la comisión de delitos de dicha naturaleza ${ }^{42}$; un delito que establece una prohibición penal tan amplia e indeterminada respecto los mensaje cuya difusión viene a prohibir y a castigar que podrá desalentar a los ciudadanos de realizar usos de su libertad de expresión completamente legítimos, ante el temor de poder ser castigados por haberlos efectuado, lo que evidentemente limitaría dicho derecho fundamental de forma desproporcionada y obliga, consecuentemente, a tener tal figura penal por manifiestamente inconstitucional.

Más problemático es responder a la cuestión de si el delito de enaltecimiento y justificación del terrorismo y el de humillación a las víctimas del art. $578 \mathrm{CP}$, pese a su reiterado uso por parte de nuestros tribunales, resulta o no acorde con dicha libertad. Como hemos visto, y según ha señalado nuestro propio TC, en su tantas veces citada STC 112/2016, esta figura solo puede considerarse acorde con las exigencias derivadas del necesario respeto a la libertad de expresión en la medida en que se limite a castigar aquellos actos de legitimación o alabanza del terrorismo o de los terroristas o de denigración y menosprecio a sus víctimas que generen un riesgo real de comisión de futuros actos terroristas por parte de sus receptores, al actuar como instrumentos idóneos de incitación implícita a la comisión de cualquier delito de dicha naturaleza por parte de dichos sujetos. Esto es, en la medida en que actúen como instrumentos de inducción indirecta de la comisión de delitos terroristas en general y no de uno concreto y determinado.

que desenmascara la ya más que evidente militancia de nuestro ordenamiento punitivo en las filas de las llamadas democracias autoritarias o democracias de carácter formal Op. cit. ant. p. 302.

42 GALÁN MUÑOZ, A. Op. cit. ant. 128 y ss. 
Nos encontramos, por tanto, ante una figura que, a diferencia de la de adoctrinamiento activo del art. 577. 2 CP, sí que define claramente el contenido de los mensajes que quedan prohibidos por su tipo de injusto, ya que solo puede castigar la difusión pública de aquellos mensajes que enaltecen o justifican los delitos que lo terroristas cometen o a quienes los ejecutan o la mera comunicación de los mensajes que humillen y denigren a sus víctimas.

Pero además, y esto no debe olvidarse, estamos ante un delito que solo castiga la difusión de dichos mensajes en la medida en que dicha conducta incremente realmente el riesgo de comisión de futuros ataques terroristas por parte de sus destinatarios.

No será, por tanto, suficiente con que el mensaje enaltezca o justifique al terrorismo o a los terroristas, o con afecte al honor de una o incluso de todas las víctimas del terrorismo, ni con que provoque la repulsa social mayoritaria o sea incluso idóneo para provocar el odio, el rechazo o simplemente sea adecuado para generar un clima hostil para un determinado colectivo de posibles víctimas o para apoyar su mantenimiento. Para que este delito se pueda tener por constitucional se requiere que su tipicidad quede limitada al castigo de aquellos mensajes que realmente pueda impulsar la comisión por parte de sus receptores de algún delito terrorista. No de uno en concreto, definido o definible, sino de cualquiera de ellos, lo que obliga a analizar la idoneidad inductora de cada mensaje enaltecedor, justificador o denigratorio para inducir a cometer tal clase de delitos, algo que, como ya hemos señalado anteriormente hará necesario que se tenga que analizar no solo quien sea el que emite el mensaje en cuestión (no será lo mismo que lo haga un conocido líder político o religioso que un completo desconocido sin prácticamente seguidores dentro o fuera de la red), quienes sean sus posibles receptores (no se podrá valorar igual que se difunda ante personas completamente contrarias a los postulados y métodos terroristas que ante gente afín a los mismos y que han sido captados precisamente por serlo) y también las concretas circunstancias 
históricas que rodean su emisión o difusión (no es igual que el mensaje transmitido apoye y legitime los actos de una organización o movimiento terrorista todavía activo que los de uno ya desparecido o completamente inactivo $)^{43}$.

Múltiples y muy variados son, por tanto, los factores a tener en cuenta a la hora de valorar si la difusión de un mensaje presenta la peligrosidad inductora que la podría hacer entrar en el ámbito típico de esta figura delictiva, lo que obliga a nuestra jurisprudencia, hasta ahora un tanto errática a la hora de realizar esta valoración, a ser muy cautelosa a la hora de enjuiciar esta cuestión.

De hecho, y precisamente en relación con este tema, si algo hay que criticar a la configuración dada al delito del art. 578 $\mathrm{CP}$ por la interpretación que del mismo han mantenido finalmente nuestro Tribunal Constitucional y nuestros tribunales, esto es que delimite la lesividad que define el mensaje típico de esta figura y legitima su sanción penal, poniéndola en relación con la idoneidad ex ante que el mensaje en cuestión tenga para inducir a sus posibles receptores a cometer cualquier delito terrorista y no de uno en concreto, algo que, sin duda y como sucedía en la delimitación de los mensajes adoctrinadores típicos del art.

43 En tal sentido, destaca MIRA BENAVENT, J. como la interesante STS 378/2017, de 25 de mayo, absolvió al acusado por delito de enaltecimiento terrorista por la difusión en redes sociales de expresiones laudatorias de los GRAPO del tipo "Llámame terrorista si grito VIVA LOS GRAPO!!" u “;Ojalá vuelvan los GRAPO, y os pongan de rodillas!”, precisamente y entre otras razones, porque "“" a) inexistencia de un contexto de violencia terrorista relacionado con los "Grapo». Esta organización desapareció hace años y no comete atentados; b) las publicaciones que se atribuyen al acusado, en el año 2012, no coincidían con acciones de esta organización terrorista, "Op. cit. ant. p. 318. En este mismo sentido, resulta también destacable que dicha resolución excluya la posibilidad de apreciar este delito en el caso enjuiciado al no haberse constatado que los hechos realizados se hubiesen llevado a cabo con "...la «tendencia», en la voluntad del autor, a querer incitar efectiva y realmente la comisión de delitos de terrorismo. $\mathrm{Ni}$ aún de manera indirecta", lo que, a nuestro modo de ver, deja a las claras que, al ser la idoneidad incitadora necesario elemento delimitador la conducta típica de este delito, debe ser abarcada por el dolo de su autor para poder ser considerado y castigado como tal. 
577.2 CP, desdibuja notablemente el referente desde el que se tiene que calcular dicha idoneidad y dota a esta figura de una notable inseguridad.

Así, si para apreciar este delito basta con que el mensaje enaltecedor, justificante o humillante transmitido pueda incitar a cometer cualquier delito terrorista, ¿desde cuál de ellos deberemos valorar su peligrosidad? ¿Desde todos? Si la respuesta a dicha pregunta fuese positiva y teniendo en cuenta la amplia variedad de delitos que pueden llegar a ser considerados terroristas conforme a la delimitación que de los mismos hace el art. $573 \mathrm{CP}$ (desde los asesinatos hasta los delitos de hacking o daños informáticos) ¿no se estará desdibujando tanto el referente del riesgo exigido por el tipo de injusto de este delito que su exigencia dejará de tener realmente trascendencia delimitadora alguna, ya que siempre se podrá apreciar? Pero, además, y por otra parte, si el riesgo de generación de cualquier posible delito terrorista permite considerar difundido el discurso propio de este delito ¿ello no supone que se asimilen y se castiguen igualmente mensajes que pueden incentivar a cometer delitos de tan diversa gravedad y naturaleza como los de asesinato, los de daños o, incluso, los de falsedades documentales terroristas, si finalmente prospera, como parece que prosperará, la última propuesta de reforma planteada en relación a esta clase de delitos? ${ }^{44}$

44 Así, si sucederá si se aprueba, como parece que va a pasar, la Proposición de Ley Orgánica por la que se modifica la Ley Orgánica 10/1995, de 23 de noviembre, del Código Penal, para transponer Directivas de la Unión Europea en los ámbitos financiero y de terrorismo, y abordar cuestiones de indole internacional. (BOCG 16 de marzo de 2018) cuyo artículo único establece que se modificará el 1 del artículo $573 \mathrm{CP}$, para pasar a darle el siguiente tenor literal “...«1. Se considerarán delitos de terrorismo la comisión de cualquier delito grave contra la vida o la integridad fisica, la libertad, la integridad moral, la libertad e indemnidad sexuales, el patrimonio, los recursos naturales o el medio ambiente, la salud pública, de riesgo catastrófico, incendio, de falsedad documental, contra la Corona, de atentado y tenencia, tráfico y depósito de armas, municiones o explosivos, previstos en el presente Código, y el apoderamiento de aeronaves, buques $u$ otros medios de transporte colectivo o de mercancias, cuando se llevaran a cabo con cualquiera de las siguientes finalidades:»"(la negrita es nuestra). 
Evidentemente, si la idoneidad incitadora de cada uno de los mensajes enaltecedores, justificadores o humillantes que podrían tener cabida en el delito del art. $578 \mathrm{CP}$ se analiza con respecto a la posible comisión de todos y cada uno de los muy variados posibles delitos terroristas ello llevaría a que prácticamente todos esos mensajes, sobretodo, si se difunden de forma pública $\mathrm{y}$, consecuentemente, ante un grupo numeroso y variopinto de posibles receptores, tuviesen que ser considerados como idóneos para poder incitar a alguno de ellos a cometer alguno de estos delitos y típicos de la referida figura, con lo que la delimitación del delito de enaltecimiento como un delito de aptitud lesiva o peligro hipotético que han mantenido nuestros tribunales tan solo serviría para excluir de su tipo de injusto aquellas difusiones de mensajes que, bien por realizarse en contextos muy controlados y limitados y con personas nada afines al terrorismo o bien, por aludir a actividades terroristas completamente superadas (p. ej. las del GRAPO), no presentasen idoneidad incitadora o lesiva alguna con respecto a la posible realización futura de ningún posible delito terrorista.

Sin embargo, si prestamos un poco de atención a la aplicación que han ido realizando nuestros tribunales de este delito en sus diferentes resoluciones para considerarlo acorde a nuestra Carta Magna conforme a lo afirmado en la tantas veces citada STC 122/2016, nos daremos cuenta de que los mismos se han encargado de restringir y acotar en cierta medida el referente desde el cual debe valorarse la potencialidad inductora propia y exigida por los mensajes típicos del art. 578 CP. Así, si bien es cierto que tanto nuestro Tribunal Supremo, como nuestra Audiencia Nacional no han dejado de repetir que la potencialidad o idoneidad inductora requerida por este delito no debe estar referida a un delito terrorista concreto, acotado y definido o definible, también han insistido, (como, por ejemplo, sucedió en la STS referida al caso Valtónyc), en que resulta fundamental que el mensaje en cuestión resulte adecuado o idóneo para fomentar la comisión de delitos violentos contra los sujetos a los que el terrorismo ataca, algo que, si bien no supone tener que constatar 
la idoneidad inductora referida a un delito concreto, sí que limita los mensajes cuya difusión podría ser castigada por esta figura, al exigir que tengan que ser idóneos para incitar a que sus posibles receptores a cometer conductas terroristas violentas y no de otra naturaleza.

La aplicación del delito del art. 578 CP quedaría, por tanto, limitada a aquellos supuestos en los que se constatase la idoneidad inductora del mensaje emitido para incitar a realizar actos terroristas violentos; referente éste que, además, de dotar de cierta seguridad jurídica a la delimitación de las conductas sancionadas por el delito de enaltecimiento al acotar los actos cuya potencial y genérica incitación castigará, también permitirá que esta figura solo pueda sancionar la difusión de mensajes que presenten una cierta gravedad y homogeneidad lesiva ( $p$. ej. las que se puedan considerar idóneas para incitar a realizar lesiones, homicidios o asesinatos contra terceras personas, pero no las que puedan fomentar un simple delito de daños o contra la intimidad), lo que, en cierto modo, parece permitirá que se pueda legitimar el amplio adelantamiento que supone la prohibición y sanción penales de las conductas comunicativas contempladas en el art. 578 CP que podrán ser consideradas, en el mejor de los casos, como meramente protopreparatorias de las difusas actuaciones violentas futuras que su castigo pretenden evitar.

Actuaría así el comentado delito como el más inicial, amplio y, porque no decirlo, también cuestionable instrumento de lucha contra el discurso que el terrorismo suele utilizar. Un instrumento que, si bien, se diferenciaría de otros, como el del art. 579.1 CP, por castigar los actos de incitación no explicita a la comisión general actos terroristas y no de uno en concreto, lo que permitiría que nuestro ordenamiento responda a las exigencias europeas de incriminación de esta clase de actos de incitación indirecta, continuaría permitiendo, a diferencia de lo que hacía el delito del art. 577.2 CP, que se puedan mantener, defender y difundir los postulados, las ideas e incluso justificar los actos realizados por los terroristas y enaltecer a quienes los realizan, siempre y cuando, ello no se haga de forma y con consciencia de 
que, al hacerlo, se estaría incrementando el riesgo de realización de nuevos actos terroristas violentos.

En cualquier caso, estamos, sin duda, ante una figura que castiga conductas muy alejadas de la efectiva y real puesta en peligro de los bienes jurídicos que trata de tutelar (vida, salud, etc...) y que, por tanto, presentan una muy escasa lesividad con respecto a dichos valores, lo que sitúa la legitimidad de la existencia de este delito en un terreno ciertamente pantanoso. Justo al borde de la producción de una limitación desproporcionada y, por tanto, ilegítima e inconstitucional de un derecho tan fundamental para los Estados democráticos como es el de la libertad de expresión ${ }^{45}$.

Evidentemente, ello es un ejemplo más de como el terror que han generado los incesantes y crueles ataque terroristas sufridos en España y en muchos otros países de nuestro entorno en los últimos años nos han situado al filo de la desesperación $\mathrm{y}$ ante el abismo de considerar adecuado o incluso necesario sacrificar nuestros derechos para luchar contra quienes nos atacan sin piedad.

Sin embargo, hay que tratar por todos los medios que el miedo no nos lleve a caer en dicho abismo. No todo está ni puede estar permitido para luchar contra los terroristas y, por ello, hoy más que nunca hay que seguir insistiendo en la defensa de la vigencia y efectividad de derechos tan fundamentales como el de la libertad de expresión; una libertad cuyo respeto y de-

45 En tal sentido, señala acertadamente, a nuestro modo de ver, ALCACER GUIRAO, R. que esta figura, como el resto de las que se han incardinado dentro de las que sancionan el denominado discurso del odio, han de ser interpretadas teniendo en cuenta el conflicto que plantea su sanción con el derecho fundamental a la libertad de expresión, lo que obligará a interpretar su tipo de injusto y su aplicación a los casos concretos conforme a las exigencias derivadas del principio de proporcionalidad, evitando, en todo caso que su existencia pueda generar un efecto de desaliento en el legítimo ejercicio de dicho derecho fundamental por parte de quienes defienden algunos de los postulados que sostienen los terroristas, incluso si éstos resultan socialmente repudiables. En Op. cit. ant. p. 29 y ss. 
fensa es, precisamente, una de las cosas que nos diferencian de aquellos que, como los terroristas, pretenden imponer sus ideas y creencias mediante el uso de la violencia y el dolor.

Las verdaderas democracias deben, por tanto, defender a toda costa el mantenimiento de los principios libertarios sobre las que se crearon y, entre ellos, de los que nos permiten a todos mantener y defender toda clase de ideas y opiniones por muy cuestionables o rechazables que parezcan o nos puedan parecer a la mayoría, mientras no representen un ataque tan grave y evidente a otros valores que justifique y legitime su prohibición.

No está de más, en consecuencia, terminar este breve estudio referido a la persecución penal del discurso del odio terrorista, recordando la tal vez vieja, pero no por ello menos actual y vigente frase, erróneamente atribuida a Voltaire, que decía "Estoy en desacuerdo con lo que dices, pero defenderé hasta la muerte tu derecho a decirlo" 46 . Esperemos que dicha frase guíe la política criminal futura en materia de terrorismo.

\section{Bibliografía}

ALONSO RIMO, A. "La criminalización de la preparación delictiva través de la Parte Especial del Código penal. Especial referencia a los delitos de terrorismo" (Dir. Alonso Rimo, A. y otros) Terrorismo, sistema penal y derechos fundamentales. Ed. Tirant lo Blanch, Valencia, 2018.

- "Apología, enaltecimiento del terrorismo y principios penales", en RDPC, nº 4, 2010.

BARBER BURRUSCO, S. Los actos preparatorios del delito. Ed. Comares, Granada, 2004.

$46 \mathrm{Al}$ parecer, la celebre frase fue atribuida al conocido filósofo por su biógrafa, Evelyn Beatrice Hall, en el libro Los amigos de Voltaire, publicado en 1906. Así lo señalan BOLLER, P. F./ GEORGE, J. H. They Never Said It: A Book of Fake Misquotes, and Misleading Atributtions. Ed. Oxford University Press, New York/Oxford, 1989, p. 103 y 104. 
BERNAL DEL CASTILLO, J. “Una visión crítica del nuevo delito de provocación al terrorismo del art. 579.1" Revista de Derecho Penal no 33, 2011.

- $\quad$ "El enaltecimiento del terrorismo y la humillación de sus víctimas como formas del "discurso del odio"”, en Revista de Derecho Penal y Criminología, 3.a Época, no 16 (2016).

BOLLER, P. F./ GEORGE, J. H. -They Never Said It: A Book of Fake Misquotes, and Misleading Atributtions. Ed. Oxford University Press, New York/Oxford, 1989.

CAMPO MORENO, J. C. Comentarios a la reforma del Código penal en materia de terrorismo: L.O. 2/2015, Ed. Tirant lo Blanch, Valencia 2015.

CANCIO MELIÁ, M. "Delitos de organización: Criminalidad organizada común y delitos de terrorismo" en (Dir. DíazMaroto y Villarejo) Estudios sobre las reformas del Código penal operadas por las LO 5/2010, de 22 de junio, y 3/2011, de 28 de enero. Ed. Civitas. Cizur Menor (Navarra) 2011.

- $\quad$ "Delitos de terrorismo (arts. 571, 572, 574, 576, 576 bis y 579)", en (Dir. Álvarez García) Comentarios a la reforma penal de 2010, Ed. Tirant lo Blanch, Valencia, 2010.

CANO PAÑOS. M. A. "La reforma de los delitos de terrorismo", en Estudios sobre el Código penal reformado (Leyes Orgánicas 1/2015 y 2/2015) Ed. Dykinson, Madrid, 2015.

- "Reflexiones en torno al "viejo" y al "nuevo" terrorismo", en REIC 7 (2009), disponible en http://www.criminologia.net/pdf/reic/ano7-2009/a72009art7.pdf (últ. vis. 13-11- 2017).

- "La Reforma penal de los delitos de terrorismo en el año 2015. Cinco cuestiones fundamentales", RGDP 23 (2015), disponible en http://www.iustel.com (últ. vis. 1303-2018).

CARBONELL MATEU, J. C. "Apología de los delitos contra la seguridad interior del Estado”, en (Dir. Cobo del Rosal) 
Comentarios a la legislación penal, Tomo II: El Derecho penal del Estado democrático, Ed. Edersa Madrid, 1983. "Crítica a los sentimientos como bien jurídico-penal: el enaltecimiento del terrorismo y la humillación a las víctimas "más allá de la provocación y la injuria"”, en (Dir. Alonso Rimo, A. y otros) Terrorismo, sistema penal y derechos fundamentales. Ed. Tirant lo Blanch, Valencia, 2018.

CUERDA ARNAU, M. L. "Terrorismo y libertades políticas", disponible en https://core.ac.uk/download/pdf/61388140. pdf (últ. vis. 18-9-2018)

FUENTES OSORIO, J. L. "Concepto de "odio y sus consecuencias penales", en (Dir. Miro Llinares, F.) Cometer delitos en 140 caracteres. El Derecho penal ante el odio y la radicalización en Internet. Ed. Marcial Pons. Madrid, 2017.

GALÁN MUÑOZ, A. "¿Leyes que matan ideas frente a las ideas que matan personas? Problemas de la nueva represión de los mecanismos de captación terrorista tras la reforma del código penal de la LO 2/2015", Revista de Derecho Penal y Criminología, 3.a Época, nº. 15 (2016).

GARCÍA ALBERO, R. Comentarios al Código penal Español, Tomo II Ed. Aranzadi, Cizur Menor, 2017.

- " "La reforma de los delitos de terrorismo", en (Dir. Quintero Olivares) La reforma penal de 2010: análisis y comentarios. Ed. Aranzadi. Cizur Menor, 2010.

GÓMEZ MARTÍN, V. "Discurso del odio y principio del hecho" en (Dir. Mir Puig, S y otros) Protección penal de la libertad de expresión e información. Una interpretación constitucional. Ed. Tirant lo Blanch, Valencia, 2012.

GÓMEZ RIVERO, M. C. La inducción a cometer el delito. Ed. Tirant lo Blanch, Valencia, 1995.

LÓPEZ PEREGRÍN, C. "¿Lucha contra la criminalidad mediante el cumplimiento íntegro y efectivo de las penas?" REIC 1 (2003), disponible en http://www.criminologia. net/pdf/reic/ano1-2003/a12003art2.pdf (últ. vis. 2-112015). 
MANJÓN CABEZA, A. “Apología del terrorismo”, en (Dir. Octavio de Toledo y otros) Estudios penales en recuerdo del profesor Ruiz Antón, Ed. Tirant lo Blanch, 2004, p. 580.

MIRA BENAVENT, J. "El delito de enaltecimiento del terrorismo, el de humillación a las víctimas del terrorismo y la competencia de la Audiencia Nacional: ni delito, ni terrorismo, ni competencia de la Audiencia Nacional", en (Dir. Alonso Rimo, A. y otros) Terrorismo, sistema penal $y$ derechos fundamentales. Ed. Tirant lo Blanch, Valencia, 2018.

MIR PUIG, S. Derecho penal. Parte General. Ed. Reppertor, Barcelona, 2015.

MIRO LLINARES, F. "Derecho penal y 140 caracteres. Hacia una exégesis restrictiva de los delitos de expresión", (Dir. Miro Llinares, F.) Cometer delitos en 140 caracteres. El Derecho penal ante el odio y la radicalización en Internet. Ed. Marcial Pons. Madrid, 2017.

MUÑOZ CONDE, F. Derecho penal. Parte Especial. Ed. Tirant lo Blanch, Valencia, 2017.

NÚNEZ CASTAÑO, E. Los delitos de colaboración con organizaciones y grupos terroristas. Ed. Tirant lo Blanch, Valencia, 2013.

- "Tendencias político criminales en materia de terrorismo tras la L. O. 2/2015, de 30 de marzo: la implementación de la normativa europea e internacional", en Revista Penal, $n^{\circ} 37,2016$.

POPPER, K. La sociedad abierta y sus enemigos. Ed. Paidós, Barcelona, 2006.

PORTILLA CONTRERAS, G. "El retorno de la censura y la caza de brujas anarquistas", en (Dir. Miro Llinares, F.) Cometer delitos en 140 caracteres. El Derecho penal ante el odio y la radicalización en Internet, Ed. Marcial Pons. Madrid, 2017.

QUINTERO OLIVARES, G. (Dir. Quintero Olivares). Comentarios al Código penal español. Tomo I. Ed. Aranzadi, Cizur Menor, 2016. 
RAMOS VÁZQUEZ, J. A. "Presente y futuro del delito de enaltecimiento y justificación del terrorismo", en AFCUC, $12,2008$.

RODRÍGUEZ MONTAÑÉS, T. Libertad de expresión, discurso extremo y Delito. Una aproximación desde la constitución a las fronteras del derecho penal. Ed. Tirant lo Blanch, Valencia, 2011.

ROLLNER LIERN, G. "El discurso del odio y los límites de a libertad de expresión: de "la zona intermedia" a los estándares internacionales", en Cometer delitos en 140 caracteres. El Derecho penal ante el odio y la radicalización en Internet. Ed. Marcial Pons. Madrid, 2017

VIVES ANTÓN, T. S. Terrorismo y proceso penal acusatorio. Ed. Tirant lo Blanch, Valencia, 2006. 